\title{
Differentiation Strategy, CSR, And Real Activities Earnings Management: Evidence From Korea
}

Sungbin Chun, Sogang University, South Korea

Eunho Cho, New York Institute of Technology, China

\begin{abstract}
We empirically investigate whether a differentiation strategy constrains real activities earnings management (RAEM). Further, considering corporate social responsibility (CSR) activities are a popular tool of differentiation strategy, we examine whether interactive synergy between CSR activities and the differentiation strategy strengthens the negative relationship between differentiation strategy and RAEM. Using a sample of 659 firm-year observations of Korean manufacturing listed firms during 2005-2010, we find that differentiation strategy is negatively associated with RAEM, suggesting that firms pursuing a differentiation strategy are likely to refrain from managing earnings using RAEM that goes against their strategy. We also observe that interactive synergy between differentiation and CSR strengthens the negative relationship between differentiation strategy and RAEM, implying that synergy effect between CSR and differentiation strategy even more constrains RAEM that is in conflict with both CSR and differentiation strategy. These findings are robust after we perform sensitivity tests. This study contributes to the literature by providing the first evidence on the relationship between differentiation strategy and RAEM and the moderating role of CSR activities on the relationship.
\end{abstract}

Keywords: Corporate Social Responsibility; Cost Leadership Strategy; Differentiation Strategy; And Real Activities Earnings Management

\section{INTRODUCTION}

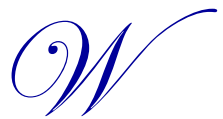
e examine whether a differentiation strategy as compared to a cost leadership strategy constrains real activities earnings management (RAEM). Moreover, given that corporate social responsibility (CSR) activities have a close relationship with the differentiation strategy (McWilliams, Siegel \& Wrignt, 2006; Boehe \& Cruz, 2010), we explore whether CSR activities play a significant moderating role in the relationship between differentiation strategy and RAEM. Recently, managers are known to employ RAEM extensively since the passage of Sarbanes-Oxley Act in 2002 (Graham, Harvry \& Rajgopal, 2005; Cohen, Dey, \& Lys, 2008). In Korea setting, Chun, Kwon, Kim, Kim and Lee (2012) also report survey results using 116 CFOs of Korean listed firms that firms aggressively use RAEM such as R\&D, advertising, and administration expenses if they have to manage earnings. In accounting literature, accrual-based earnings management (ABEM) and RAEM have been much addressed. Although both are the same in that they are a manager's intentional behavior to mislead stakeholders by managing earnings, RAEM is fundamentally different from ABEM regarding the timing of earnings management, change of the underlying operation activities, litigation \& audit risk exposure, and the effect on firm value (Kim \& Sohn, 2013). Some studies document that unlike ABEM, RAEM can increase the cost of equity capital (Chun \& Cha, 2012; Kim \& Sohn, 2013) and decrease firm value (Gunny, 2005; Kim, Bae, Goh, 2009). Also RAEM distorts normal operating cycle, resulting in changes in current and future cash flow. However, RAEM study has received less attention as compared to accrual-based earnings management (Graham et al., 2005).

Product differentiation strategy can be associated with earnings management. For example, A firm's growth and investment characteristics may influence earnings quality (Dechow, Ge \& Schrand, 2010). In a similar context, the 
product type, the degree of industry competition, and the level of capital intensity can also influence earnings quality (Lev, 1983).

Regarding RAEM and differentiation strategy, two contradictory views exist. R\&D expenses (Baber, Fairfield, \& Haggard, 1991; Osma, 2008) and advertising expenses (Cohen, Mashruwala \& Zach, 2009) are found to be a primary means of RAEM to boost earnings. For firms that have a high level of R\&D and advertising expenses relative to sales revenue, it may be relatively easy to manage earnings by using R\&D and advertising expenses. On the other hand, firms with high R\&D and advertisement intensity (i.e. firms pursuing differentiation strategy) focus on enhancing product quality and their brand \& corporate image. Accordingly, firms pursuing the differentiation strategy have strong incentives to constrain RAEM not only to maintain the high level of investing activities such as $\mathrm{R} \& \mathrm{D}$ and advertising expenses, but also to protect its intangible brand image because RAEM such as sales price discount and inventory overproduction are highly likely to damage its brand image. Hence, we expect that the differentiation strategy has a negative relationship with RAEM.

CSR activities have grown rapidly during the last decade (Harjoto \& Jo, 2011). CSR can be considered an important strategy to increase firm value (Porter \& Kramer, 2006). For example, $95 \%$ of the Global 250 firms issue a CSR report to the public (Accenture, 2014). Reflecting these concerns in the business, prior studies show that CSR activities constrain RAEM (Kim, Park \& Wier, 2012; Lim \& Choi, 2013; Cho \& Chun, 2016). However, little is known as to whether CSR activities strengthen the relationship between the differentiation strategy and RAEM. We predict that CSR activities can make the synergy effect with the differentiation strategy. Thus, we explore whether CSR can be a moderating variable in the negative relationship between differentiation strategy and RAEM.

We use a sample of 659 firm-year observations of Korean listed manufacturing firms during 2005-2010. Product strategy (differentiation versus cost leadership strategy) is classified based on the level of R\&D and advertisement intensity following the methodology of Hambrick (1983). We measure RAEM using Roychowdhury (2006) methodology. KEJI Index is used to proxy for the level of a firm's CSR activities.

We find that differentiation strategy is negatively associated with RAEM. This result means that firms pursuing a differentiation strategy are less likely to manage earnings using RAEM than those pursuing a cost leadership strategy. We also observe that interactive synergy between the differentiation and CSR strengthens the negative relationship between the differentiation strategy and RAEM.

This study contributes to the CSR and earnings management literature as follows. First, to the best of our knowledge, this is the first study exploring whether differentiation strategy is negatively associated with RAEM confirming the argument that a conflict between differentiation strategy and RAEM exists. Second, this study also provides empirical evidence on the interaction effect between CSR and differentiation strategy on the relationship between differentiation strategy and RAEM, implying that firms with high CSR activities strengthen the negative relationship between the differentiation strategy and RAEM. Third, we provide evidence using a sample of listed firms in Korea, one of the Asian countries that are reported to have a different level of CSR activities and legal environment (Dhaliwal, Radhakrishnan, Tsang \& Yang, 2012) compared to Western countries. CSR activities in developing countries have received little attention compared to Western countries' CSR activities many researchers focus on (Gao, 2011). Earnings management practice also varies across countries (Leuz, Nanda, \& Wysocki, 2003). Different countries have a different degree of CSR activities, legal system and investor protection (Reinhardt, Stavins \& Vietor, 2008). For example, the stakeholder orientation of Korea and the USA ranks $26^{\text {th }}$ and $25^{\text {th }}$ among 31 countries, respectively, whereas analyst forecast errors of Korea and the USA rank $31^{\text {st }}$ and $1^{\text {st }}$ (Dhaliwal et al., 2012). These rankings indicate that Korean information environment is different from the USA. Thus, this study can provide supplementary evidence on the moderating role of CSR on the relationship between the product strategy and RAEM in the Korean setting.

In the next section, we provide a literature review and develop the hypotheses. The third section describes the research design. The fourth section discusses the empirical results, and the final section concludes. 


\section{LITERATURE REVIEW AND HYPOTHESES DEVELOPMENT}

Figure 1 shows our research model. Our study investigates whether the differentiation strategy is associated with a firm's RAEM (H1) and whether CSR activities strengthen the relationship between the differentiation strategy and RAEM (H2).

Figure 1. Research Model

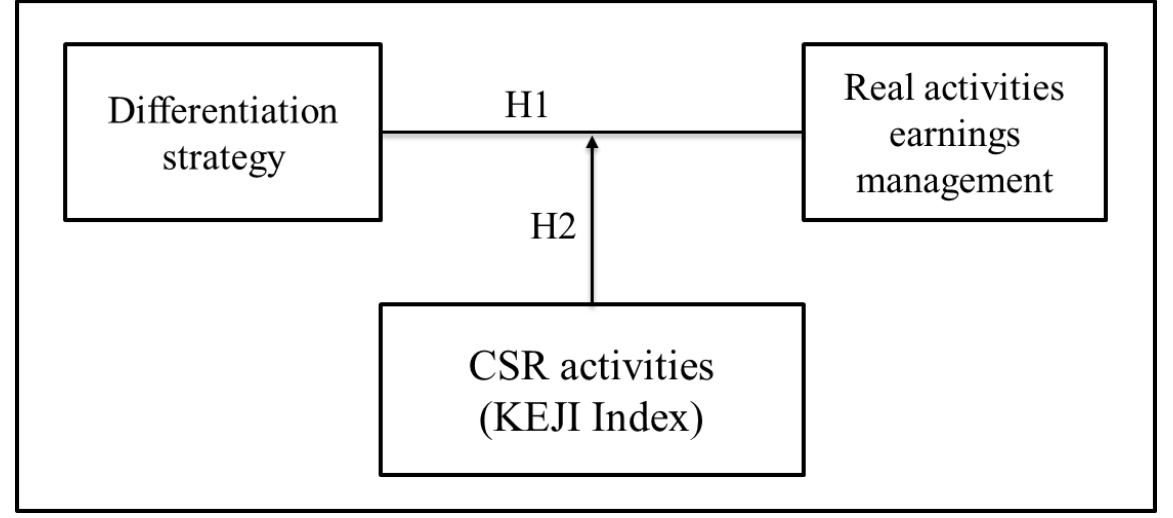

\subsection{RAEM}

In accounting literature, RAEM and accrual-based earnings management have common characteristics in that managers intentionally try to alter accounting number to mislead stakeholders by using their discretionary management decision power. However, RAEM is essentially different from accrual-based earnings management as follows. First, regarding the timing of earnings management, RAEM is done before fiscal year-end, whereas accrualbased earnings management is accomplished after fiscal year-end. Second, RAEM needs to change underlying operation activities, mostly accompanying cash transactions. On the contrary, accrual-based earnings management does not alter operating activities and involve cash transactions because it changes accounting methods or estimates. Third, RAEM can avoid regulator's scrutiny, litigation, and audit risk (Gunny, 2005) because managers make real transactions affecting the current and future cash flow, whereas accrual-based earnings management can be exposed to regulator's scrutiny, litigation, and audit risk because managers seem to change accounting methods without a good reason after fiscal year-end. Lastly, RAEM is more costly than accrual-based earnings management due to distorted normal operating cycle. Unlike RAEM abnormally changing the current and future cash flow, managers mostly use their discretionary power in choosing the accounting methods after fiscal year end for accrual-based earnings management (Gunny, 2005; Kim, Goh \& Koh, 2008).

Recently, managers are known to employ RAEM together with or replacing accrual-based earnings management (Cohen et al., 2008; Zang, 2012). In Korea setting, using 116 CFOs of Korean listed companies, Chun et al. (2012) report that managers also aggressively employ RAEM such as R\&D, advertisement, and administration expenses if they need to manage earnings. Reflecting these interests in the business field, prior studies report evidence of particular account of RAEM. For example, managers are known to manage earnings before fiscal year end by using sales discount (Jackson \& Wilcox, 2000), overproduction of inventory (Thomas \& Zhang, 2002), cutting R\&D expenses (Dechow \& Sloan, 1991; Bushee, 1998; Bens, Nagar \& Wong, 2002; Cheng, 2004; Osma, 2008), and decreasing advertisement expenses (Cohen et al., 2009).

Lately, Gunny (2005) provides evidence that RAEM can decrease firm value. In Korea setting, Kim et al. (2009) also show that RAEM negatively affects firm value. In a similar context, RAEM increases the cost of equity capital (Chun \& Cha, 2012; Kim \& Sohn, 2013). Importantly, Roychowdhury (2006) suggests the comprehensive RAEM measurement models that include abnormal discretionary expenses, abnormal inventory production, and abnormal 
operating cash flow. However, RAEM has not received much attention in the study relative to accrual basis earnings management (Graham et al., 2005).

\subsection{Differentiation Strategy and RAEM}

Product differentiation strategy can be associated with RAEM. According to Porter (1980), the differentiation strategy emphasizes a reputation for quality, a good firm image, and product design, leading to large spending of advertising and promotion (Miller, 1986). In contrast, the cost leadership strategy focuses on providing standard and high volume goods at a low price. To this end, it emphasizes minimization of manufacturing costs and R\&D and advertising expenses (Miller, 1986). On the other hand, Dechow et al. (2010) report that earnings quality can be influenced by the business environment where the company operates and by the specific firm characteristics such as company performance, growth and investment, and company size. Earning persistence, one of the earnings quality measurements, is systematically associated with the several factors: product type, the level of industry competition, the level of capital intensity, and firm size (Lev, 1983). Regarding the business environment, studies report mixed results in earnings quality. Cheng, Man and Yi (2013) indicate that the market competition increases earnings quality. Li (2010) also shows that market competition improves disclosure quality. On the other hand, firms doing business in the competitive market seem to have significant internal control weakness, indicating that competitive market decreases internal control effectiveness (Kim \& Kim, 2015). However, little is known to date about the association between a firm's product strategy and RAEM.

Firms pursuing the differentiation strategy need to constrain RAEM because RAEM can harm the differentiation strategy. More specifically, we expect that a firm pursuing a differentiation strategy has a negative relationship with RAEM for the following reasons. First, RAEM can damage product quality by reducing R\&D expenses and a good corporate image by cutting advertising expenses. RAEM can also badly affect the relationship between a company and employees because RAEM reduces SGA expenses such as employee welfare expenses without good reason. Second, when a firm pursuing a differentiation strategy sells products at a significant discount, the price may not bounce back to its normal level in the next period, harming its brand image. Moreover, since the differentiated brand image mainly comes from uniquely attractive and quality products, the sales discount may change customers' perception about the product. Third, when the firm manages earnings by giving a lenient credit term to their customers, its policy may damage its brand image because loyal clients willing to pay a premium for the product may perceive such a policy as a signal to make them undistinguishable from other cheap clients. Moreover, the credit policy causes an increase in bad account receivables and hurts its firm value. Lastly, a firm can produce excessive amount of products to increase operating income intentionally. However, its decision to overproduce inventory is likely to decrease product quality by deviating from the normal operating cycle, increase a warehouse inventory cost, and cause employee complaints due to unnecessary overtime work. Thus, overproduction of inventory to increase earnings intentionally can cause an unfavorable effect on its brand image and employee dissatisfaction, resulting in decreased firm value. Hence, we predict that the differentiation strategy can constrain RAEM. Based on this line of arguments, we establish the following hypothesis (H1):

Hypothesis 1: Other things being equal, a firm's differentiation strategy is negatively associated with RAEM.

\subsection{Moderating Effect of CSR}

CSR activities have grown significantly (Harjoto \& Jo, 2011) and become one of the most significant business strategies the managers have to consider to enhance firm value (Porter \& Kramer, 2006). 68\% of the 34 papers reviewed by Beurden \& Gössling (2008) show that the relationship between CSR and financial performance is positive. This finding implies that CSR activities can enhance firm value. Moreover, according to the survey report by Accenture, 93\% of the surveyed CEOs consider CSR activities important to increase firm value and $95 \%$ of the Global 250 companies annually report their CSR activities to the public (Accenture, 2014). Reflecting these interests in the business community, researchers have investigated whether CSR plays a significant role in constraining earnings management based on ethical and stakeholder perspective. 
Table 1 shows the summary of prior studies on the relationship between CSR and earnings management. Initially, researchers explore whether CSR affects accrual-based earnings management based on the ethical perspective of CSR activities. As a result, the majority of the prior studies (Choi \& Pae, 2011; Kim et al., 2012; Choi \& Moon, 2013) document that CSR is significantly and negatively associated with accrual-based earnings management. Recently, a few studies investigate if CSR activities are associated with RAEM. Based on ethical perspective, Kim et al. (2012) support the argument that CSR activities can constrain managers' RAEM using the 18,160 firm-year observations in the U.S. during 2002-2009. In Korea setting, Lim \& Choi (2013) show that CSR is negatively associated with RAEM as well. Focusing on the stakeholder perspective of CSR activities, Cho \& Chun (2016) also provide supporting evidence that CSR is negatively associated with RAEM using 1,432 firm-year observations in the Korean capital market during 2005-2010.

Table 1. Summary of Prior Studies on the Relationship between CSR and Earnings Management

\begin{tabular}{|c|c|c|c|c|}
\hline Authors & Period & Sample & CSR measure & Major Result \\
\hline \multicolumn{5}{|c|}{ The relationship between CSR and RAEM } \\
\hline $\begin{array}{l}\text { Cho and Chun } \\
\text { (2015) }\end{array}$ & $\begin{array}{c}1,432 \\
(2005-2010)\end{array}$ & Korean listed firms & KEJI Index & $\begin{array}{l}\text { The CSR activities are negatively associated } \\
\text { with RAEM based on stakeholder perspective. }\end{array}$ \\
\hline $\begin{array}{l}\text { Lim and Choi } \\
\text { (2013) }\end{array}$ & $\begin{array}{c}215 \\
(2009-2011)\end{array}$ & Korean listed firms & ESG Index & $\begin{array}{l}\text { The CSR activities are negatively related to } \\
\text { RAEM based on ethical perspective. }\end{array}$ \\
\hline $\begin{array}{l}\text { Kim, Park, and } \\
\text { Wier (2012) }\end{array}$ & $\begin{array}{c}18,160 \\
(2002-2009)\end{array}$ & U.S. firms & KLD Index & $\begin{array}{l}\text { The CSR activities are negatively associated } \\
\text { with RAEM based on ethical perspective. }\end{array}$ \\
\hline \multicolumn{5}{|c|}{ The relationship between CSR and ABEM } \\
\hline $\begin{array}{l}\text { Choi and Moon } \\
\text { (2013) }\end{array}$ & $\begin{array}{c}4,573 \\
(2002-2009)\end{array}$ & Korean listed firms & KEJI Index & $\begin{array}{l}\text { The CSR activities are negatively related to } \\
\text { accrual based earnings management. }\end{array}$ \\
\hline $\begin{array}{l}\text { Lim and Choi } \\
\text { (2013) }\end{array}$ & $\begin{array}{c}215 \\
(2009-2011)\end{array}$ & Korean listed firms & ESG Index & $\begin{array}{l}\text { The CSR activities are insignificantly related } \\
\text { to ABEM based on ethical perspective. }\end{array}$ \\
\hline $\begin{array}{l}\text { Kim et al. } \\
(2012)\end{array}$ & $\begin{array}{c}18,160 \\
(2002-2009)\end{array}$ & U.S. firms & KLD Index & $\begin{array}{l}\text { The CSR activities are negatively associated } \\
\text { with ABEM based on ethical perspective. }\end{array}$ \\
\hline $\begin{array}{l}\text { Choi and Pae } \\
(2011)\end{array}$ & $\begin{array}{c}242 \\
(2004)\end{array}$ & Korean listed firms & $\begin{array}{l}\text { Ethical commitment } \\
\text { Index (ECI) } \\
\text { developed by Choi } \\
\text { and Jung (2008) }\end{array}$ & $\begin{array}{l}\text { The level of ethical commitment is negatively } \\
\text { associated with ABEM. }\end{array}$ \\
\hline $\begin{array}{l}\text { Prior, Surroca, } \\
\text { and Tribó } \\
(2008)\end{array}$ & $\begin{array}{c}593 \\
(2002-2004)\end{array}$ & $\begin{array}{l}\text { Firms from } 26 \\
\text { countries }\end{array}$ & SiRi Pro ${ }^{\mathrm{TM}}$ data & $\begin{array}{l}\text { The CSR activities are positively associated } \\
\text { with ABEM. }\end{array}$ \\
\hline
\end{tabular}

RAEM can damage the differentiation strategy due to abnormal change of current and future cash flows. Thus, the differentiation strategy is highly likely to constrain RAEM to prevent RAEM from harming the strategy. Moreover, given that a firm pursuing the product differentiation strategy emphasizes the firm image and brand perceived by stakeholders such as customers, community, and employees, the differentiation strategy can be in conflict with RAEM. CSR activities emphasizing the good relationship with stakeholders are also known to be closely related to differentiation strategy. Many studies (e.g., Porter, 1980; McWilliams \& Siegel, 2001; Siegel \& Vitaliano, 2007) indicate that differentiation strategy is closely associated with CSR activities. CSR also is a means of enhancing product differentiation (McWilliams \& Siegel, 2001; Siegel \& Vitaliano, 2007; Boehe \& Cruz, 2010). Hence, we posit that CSR activities can support a firm's product differentiation strategy. Based on the previous arguments, we expect that interactive synergy between CSR and differentiation strategy strengthens the negative relationship between the differentiation strategy and RAEM. We thus suggest the following hypothesis (H2):

Hypothesis 2: Other things being equal, a firm's CSR activities strengthen the negative relationship between the differentiation strategy and RAEM. 


\section{RESEARCH METHOD}

\subsection{Empirical Model}

To test the moderating effect of a firm's product strategy on the relationship between CSR activities and RAEM, we employ multivariate regression Equation (1) as follows:

$$
\begin{aligned}
& R A E M_{-} P R O X Y_{i . t}=\alpha_{0}+\alpha_{1} A D J \_C S R_{i, t}+\alpha_{2} D I F F_{i, t}+\alpha_{3} A D J \_C S R * D I F F_{i, t}+\alpha_{4} A B S \_D A_{i . t} \\
& +\alpha_{5} \operatorname{SIZE}_{i, t}+\alpha_{6} \text { GROWTH }_{i, t}+\alpha_{7} A D J_{-} R O A_{i, t}+\alpha_{8} B I G 4_{i, t} \\
& +\alpha_{9} \text { LEVERAGE }_{i, t}+\alpha_{10} \text { EQUITY }_{i, t}+\alpha_{11} \text { GOVERNANCE }_{i, t} \\
& +\alpha_{12} F_{I R M A G E_{i, t}}+\sum I N D_{i, t}+\sum Y E A R_{i, t}+\varepsilon_{i, t}
\end{aligned}
$$

where, for company $i$ in period $t$ :

\section{Dependent Variables}

$\begin{array}{ll}\text { RAEM_PROXY: } & \\ C O M B \_R M & =-A B \_C F O+A B \_P R O D-A B \_E X P,{ }^{\mathrm{i}} \\ N E G A \_A B \_E X P & =(-1) * A B \_E X P ; \\ A B \_P R O D & =\text { abnormal production costs; and } \\ N E G A \_A B \_C F O & =(-1) * A B \_C F O .\end{array}$

Variable of Interest

ADJ_CSR

= natural logarithm of adjusted CSR score (Original KEJI CSR score - soundness score fairness score);

$=$ indicator variable that equals 1 if firms pursue the differentiation strategy measured by

$D I F F$ $R \& D$ and advertisement intensity measured by the mean of R\&D expenditures and advertisement divided by sales for 6 years, respectively, and 0 otherwise; and

$A D J \_C S R^{*} D I F F \quad=$ interaction term, measured by $A D J \_C S R$ times DIFF.

\section{Control Variables}

$A B S \_D A$

SIZE

GROWTH

$A D J R O A$

$B I G 4$

LEVERAGE

EQUITY

GOVERNANCE

FIRM AGE
$=$ absolute value of discretionary accruals measured using the modified Jones model including lagged ROA;

$=$ natural logarithm of total asset at the end of fiscal year;

$=$ average sales growth rate for the prior three years;

$=$ industry mean-adjusted return on assets $(\mathrm{ROA})$ in the prior year $(\mathrm{ROA}=$ income from continuing operation divided by lagged total assets);

$=$ indicator variable that is 1 if big 4 accounting firms audit the company, and 0 otherwise;

$=$ total liability divided by total assets at the end of fiscal year;

$=$ indicator variable that is 1 if the firm has equity issuing in the following year, and 0 otherwise;

$=$ natural logarithm of total governance score measured as KCGS Index; and

$=$ natural logarithm of the number of years since the firm's establishment plus one.

\subsection{Data and Sample Selection}

We restrict the sample to 659 Korean listed manufacturing firm-year observations during 2005-2010 as shown below sample selection table. From 1,995 firm-year observations with the KEJI Index scores, we exclude firm-year observations of non-manufacturing (679), missing R\&D and advertisement data (162), non-December fiscal year end (47), no RAEM data due to less than 15 firms in KSIC tow-digit industry (122), and firms with high (low) R\&D and low (high) advertisement intensity level (326). Although most firms can have their product strategy, we select only manufacturing industry for the following reasons. First, we try to mitigate the effect of the different industry characteristics on our empirical results. Second, manufacturing sector accounts for a major portion (about 70 
percent) of the entire industry. Third, we consider the manufacturing sector an appropriate sample group in that the manufacturing industry is more associated with the product strategy employed in this study than other industries.

We obtain most financial data for the sample from KISVALUE broadly employed in the academic research in Korea. We also collect data related to R\&D and advertisement expenses from the TS2000 database that Korea Listed Companies Association provides. To get R\&D and advertisement intensities we calculate each firm's six-year average $R \& D$ and advertisement intensity measured by the mean of R\&D expenditures and advertisement divided by sales for 6 years, respectively. Based on each intensity measure, we divide the sample firms into two groups; low and high R\&D (advertisement) groups. We define a differentiation-strategy (cost advantage-strategy) firm as that with both high (low) R\&D and advertisement intensities. We thus exclude firms with mixed combinations of high (low) R\&D and low (high) advertisement intensities. Detailed sample selection process is as below:

\begin{tabular}{l|c} 
Sample Selection & $\begin{array}{c}\text { Observations } \\
\text { (firm-year) }\end{array}$ \\
\hline \multicolumn{1}{c|}{ Items } & 1,995 \\
\hline KEJI Index scores firms & 679 \\
\hline -non-manufacturing firms & 162 \\
\hline -missing R\&D and advertisement data & 47 \\
\hline -non-December fiscal year end & 122 \\
\hline -no RAEM data due to less than 15 firms in KSIC two-digit industry & 326 \\
\hline - firms with high(low) R\&D and low(high) advertisement intensity level & 659 \\
\hline Final sample & \\
\hline
\end{tabular}

As a dependent variable, we employ $C O M B_{-} R M$ as a proxy for the level of RAEM. The DIFF variable is the independent variable of interests. The $A D J_{-}^{-} C S R^{*} D I F F$ variable, a moderator, is included to test the second hypothesis that CSR moderates the relationship between the differentiation strategy and RAEM. We include various control variables in the regression models to avoid omitted variable problems.

\subsection{The Level of RAEM: $C O M B \_R M$}

In this study, we use Roychowdhury (2006)_ENREF_63 model to measure RAEM that are abnormal operating cash flows $\left(A B_{-} C F O\right)$, abnormal inventory production $\left(A \bar{B} \_P R O D\right)$, and abnormal $\mathrm{S} \& \mathrm{GA}$ expenses $\left(A B_{-} E X P\right)$ as shown in Equations (2), (3), and (4). Following two-digit KS IC (Korea Standard Industrial Classification) codes, we use 125 separate industry-years over 2005-2010 after deleting firm-year observations with fewer than 15 in the industry each year. The error term $\left(\varepsilon_{t}\right)$ of the each model represents the abnormal level of real activities earnings management. In Equation (2), the abnormal operating cash flow, $A B_{-} C F O$, is measured by the residual term. The abnormal cash flow mainly results from sales price discounts or loose credit terms to clients to boost sales revenues. The value of $A B \_C F O$ is expected be negative when firms manage earnings by intentionally giving favorable price or credit terms to clients to boost sales. $A B_{-} P R O D$ is the error term of Equation (3), and represents abnormal production costs that accrue from a firm's overproduction to increase net income by decreasing fixed indirect manufacturing costs per unit. $A B_{-} P R O D$ is expected to be positive if a firm overproduces its products to manage earnings. $A B \_E X P$ is the error term of Equation (4), and indicates the abnormal level of discretionary selling and general administrative (SGA) expenses. The examples of discretionary SGA expenses are R\&D, advertisement, maintenance, and employee education expenses. If a firm manipulates earnings by decreasing discretionary SGA expenses, $A B \_E X P$ is expected to be negative. In this study, following Kim et al. (2012) and Cohen et al. (2008), we calculate $C O M B \_R M$ variable to measure the overall effect of RAEM by combining the three individual components: $(-1)^{*} A B_{-} C F O+A B_{-} P R O D$ $+(-1)^{*} A B_{-} E X P$. We also employ three individual components to explore how moderating variable, $A D J C S R^{*} D \overline{I F F}$, affects each component of $C O M B_{-} R M$ as a dependent variable instead of $C O M B_{-} R M$. 


$$
\begin{aligned}
& \text { CFO }_{t} / A_{t-1}=\alpha_{0}+\alpha_{1}\left(1 / A_{t-1}\right)+\alpha_{2}\left(S_{t} / A_{t-1}\right)+\alpha_{3}\left(\Delta S_{t} / A_{t-1}\right)+\varepsilon_{t} \\
& \text { PROD }_{t} / A_{t-1}=\alpha_{0}+\alpha_{1}\left(1 / A_{t-1}\right)+\alpha_{2}\left(S_{t} / A_{t-1}\right)+\alpha_{3}\left(\Delta S_{t} / A_{t-1}\right)+\alpha_{4}\left(\Delta S_{t-1} / A_{t-1}\right)+\varepsilon_{t} \\
& \operatorname{DISEXP}_{t} / A_{t-1}=\alpha_{0}+\alpha_{1}\left(1 / A_{t-1}\right)+\alpha_{2}\left(S_{t-1} / A_{t-1}\right)+\varepsilon_{t}
\end{aligned}
$$

where:

$T A_{t} \quad=$ total accruals for a firm at the end of fiscal year $\mathrm{t}$;

$C F O_{t} \quad=$ cash flow from operations at the end of fiscal year $\mathrm{t}$;

$P R O D_{t}=$ cost of goods sold $+\triangle$ Inventory at the end of fiscal year $\mathrm{t}$;

$D_{S E X P_{t}}=$ discretionary expense at the end of fiscal year $\mathrm{t}$;

$A_{t} \quad=$ total assets at the end of fiscal year $\mathrm{t}$;

$A_{t-1} \quad=$ total assets at the end of fiscal year $\mathrm{t}-1$;

$S_{t} \quad=$ net sales at the end of fiscal year $\mathrm{t}$;

$S_{t-1} \quad=$ net sales at the end of fiscal year t-1;

$\Delta S_{t} \quad=$ change in net sales at the end of year $\mathrm{t}$ from fiscal year $\mathrm{t}-1$;

$\Delta S_{t-1} \quad=$ change in net sales at the end of year $\mathrm{t}-1$ from fiscal year $\mathrm{t}-2$;

\subsection{Differentiation Strategy}

The final 659 firm-year observations are divided into two groups - differentiation strategy group (340 observations) and cost leadership strategy group (319 observations) - to test the moderating effects of each firm's product strategy on the relationship between CSR activities and RAEM. Hambrick (1983) operationalizes differentiation strategy by using two concepts: (1) the level of product innovation measured by R\&D intensity (R\&D expenses divided by sales revenues) and (2) the level of marketing innovation measured by advertisement intensity (promotion expenses divided by sales revenues). Following the methodology suggested by Hambrick (1983) and later adopted in subsequent studies (McWilliams \& Siegel, 2000; Hull \& Rothenberg, 2008), we divide the sample firms into two groups by the level of R\&D intensity and advertisement intensity; differentiation-strategy group and cost leadershipstrategy group. We calculate each firm's six-year average R\&D and advertisement intensities, and based on each intensity measure, we divide the sample firms into two groups; low and high R\&D (advertisement) groups. We define a differentiation-strategy (cost advantage-strategy) firm as that with both high (low) R\&D and advertisement intensities. We create a dummy variable, DIFF that takes the value of 1 when firms belong to the differentiationstrategy group (both high R\&D and high advertisement intensities), and 0 if firms belong to the low cost-strategy group (both low R\&D and low advertisement intensities). Further, to test the moderating effect of CSR activities on the relationship between differentiation strategy and COMB_RM, we include a moderating variable, $A D J \_C S R^{*} D I F F$, measured by $A D J \_C S R$ multiplied by $D I F F$.

\subsection{The Level of CSR Activities: $A D J C C S R$}

Prior studies widely use KEJI Index score as a proxy for the level of CSR actions (e.g. Choi, Kwak \& Choe, 2010; Oh, Chang, \& Martynov, 2011; Choi, Lee \& Park, 2013; Choi \& Moon, 2013; Cho \& Chun, 2016). We use adjusted CSR score (ADJ_CSR) to proxy for a firm's CSR activities. As presented in Table 2, KEJI Index measurement consists of seven categories whose total score is 75 points. The seven categories are soundness, fairness, social contribution, customer protection and satisfaction, environmental protection activity, employee satisfaction, and economic development contribution (KEJI, 2011). However, the original KEJI Index CSR score includes soundness and fairness categories that are similar to corporate governance measurement categories (Kim \& Yoo, 2013; Cho \& Chun, 2016). Since we include corporate governance measure ${ }^{\text {ii }}$ as a control variable, we use ADJ_CSR to separate the impact of corporate governance on RAEM from the unadjusted KEJI index. We deduct the score of soundness and fairness categories from original CSR score to calculate ADJ_CSR. KEJI Index measurement is similar to the Council on Economic Priorities (CEP) Index, the Asahi Index (KEJI, 2011), and the KLD ratings (Oh et al., 2011). 
Table 2. KEJI Index Measurement Categories

\begin{tabular}{|c|c|c|c|c|c|c|}
\hline \multicolumn{7}{|c|}{ Categories (score) } \\
\hline $\begin{array}{l}\text { Soundness } \\
(20)\end{array}$ & $\begin{array}{l}\text { Fairness } \\
\text { (11) }\end{array}$ & $\begin{array}{c}\text { Social } \\
\text { contribution (7) }\end{array}$ & $\begin{array}{c}\text { Customer } \\
\text { protection \& } \\
\text { satisfaction (7) }\end{array}$ & $\begin{array}{c}\text { Environmental } \\
\text { protection } \\
\text { activity (10) }\end{array}$ & $\begin{array}{c}\text { Employee } \\
\text { satisfaction (10) }\end{array}$ & $\begin{array}{c}\text { Economic } \\
\text { development } \\
\text { contribution (10) }\end{array}$ \\
\hline $\begin{array}{l}\text { Soundness of } \\
\text { shareholder's } \\
\text { composition (7) }\end{array}$ & Fair trade (3) & $\begin{array}{l}\text { Protection of } \\
\text { underprivileged } \\
\text { class of people } \\
\text { (4) }\end{array}$ & $\begin{array}{l}\text { Protection of } \\
\text { consumer right } \\
\text { (2) }\end{array}$ & $\begin{array}{l}\text { Environmental } \\
\text { improvement } \\
\text { (4) }\end{array}$ & $\begin{array}{l}\text { Health and } \\
\text { safety of } \\
\text { workplace (2) }\end{array}$ & $\begin{array}{l}\text { Research and } \\
\text { development } \\
\text { expenditures (2) }\end{array}$ \\
\hline $\begin{array}{l}\text { Soundness of } \\
\text { investment } \\
\text { expenditures (3) }\end{array}$ & $\begin{array}{l}\text { Negligent } \\
\text { disclosure (2) }\end{array}$ & $\begin{array}{l}\text { Social } \\
\text { contribution (3) }\end{array}$ & $\begin{array}{l}\text { Product quality } \\
\text { (3) }\end{array}$ & $\begin{array}{l}\text { Environmental } \\
\text { friendly policy } \\
\text { (3) }\end{array}$ & $\begin{array}{l}\text { Investment of } \\
\text { human resource } \\
\text { (4) }\end{array}$ & Patents (1) \\
\hline $\begin{array}{l}\text { Financial } \\
\text { leverage (5) }\end{array}$ & $\begin{array}{l}\text { Fairness of } \\
\text { annual report } \\
\text { (2) }\end{array}$ & & $\begin{array}{l}\text { Advertisement } \\
\text { expenditure (2) }\end{array}$ & $\begin{array}{l}\text { Violation and } \\
\text { pollution (3) }\end{array}$ & $\begin{array}{l}\text { Wage and } \\
\text { welfare (4) }\end{array}$ & Profitability (1) \\
\hline $\begin{array}{l}\text { Investment from } \\
\text { affiliates (3) }\end{array}$ & $\begin{array}{l}\text { Ratio of outside } \\
\text { director (2) }\end{array}$ & & & & & Growth (1) \\
\hline \multirow[t]{5}{*}{$\begin{array}{l}\text { Guarantee from } \\
\text { affiliates (2) }\end{array}$} & $\begin{array}{l}\text { Participation of } \\
\text { outside director } \\
\text { (2) }\end{array}$ & & & & & $\begin{array}{l}\text { Equipment } \\
\text { investment (1) }\end{array}$ \\
\hline & & & & & & Tax payment (1) \\
\hline & & & & & & $\begin{array}{l}\text { Dividend } \\
\text { payout ratio (1) }\end{array}$ \\
\hline & & & & & & $\begin{array}{l}\text { Labor } \\
\text { productivity } \\
\text { increase rate (1) }\end{array}$ \\
\hline & & & & & & $\begin{array}{l}\text { Export } \\
\text { contribution (1) }\end{array}$ \\
\hline
\end{tabular}

Source: The 20th corporate award of economic justice (KEJI, 2011) (translated into English from Korean)

\subsection{Control Variables}

We include various control variables in the regression models to avoid omitting variables that can affect a firm's RAEM. The variables are absolute discretionary accrual $\left(A B S \_D A\right)$, firm size (SIZE), sales growth rate $(G R O W T H)$, industry mean-adjusted return on assets $\left(A D J_{-} R O A\right)$, big 4 audit firms (BIG4), financial leverage (LEVERAGE), equity offering (EQUITY), the level of corporate governance (GOVERNANCE), firm age since its establishment $\left(F I R M \_A G E\right)$, Industry dummies, and Year dummies.

First, we follow the Kothari, Leone and Wasley (2005) performance-match discretionary accrual model to measure $A B S \_D A$. $^{\text {iii }}$ The modified Jones model suggested by Kothari et al. (2005) is considered to have fewer estimation errors of discretionary accruals than other models. Cohen et al. (2008) and Zang (2012) document that firms choose either ABEM or RAEM as a means of earnings management, or simultaneously use both of them depending on the firm's cost-benefit analysis taking into consideration its business circumstances. Following Cohen et al. (2008) and Kim et al. (2012) which include $A B S_{-} D A$ as a control variable in the earnings management studies, we employ $A B S \_D A$ as a control variable. Based on prior studies, we do not predict the sign of the coefficient of $A B S \_D A$ variable.

Second, firm size is widely used in the earnings management literature. Roychowdhury (2006) suggests that firm size may explain the level of earnings management. Firm size would be positively related to earnings management (Watts \& Zimmerman, 1986). On the other hand, firm size is negatively associated with earnings management because of adequate internal control system over financial reporting of larger firms (Ball \& Foster, 1982; AshbaughSkaife, Collins \& Kenney, 2007). Other studies also report that firm size is related to CSR activities (McWilliams \& Siegel, 2000; Prior et al., 2008). Thus, we include firm size variable and do not predict the sign of the coefficient of SIZE variable. 
Third, we include growth (GROWTH) variable measured by past three year's average sales growth rate as a control variables to capture growth potential. Prior studies suggest that the positive relationship exists between growth and earnings management (Richardson, Sloan, Soliman \& Tuna, 2005; Lee, Li \& Yue, 2006; Ashbaugh-Skaife et al., 2007). Thus, we predict a positive sign of the coefficient of GROWTH.

Fourth, to control the effect of profitability on earnings management, we include $A D J R O A$ (adjusted return on assets) (Balsam et al., 1995), calculated by deducting the mean ROA of its industry from the firm's ROA. Firms that realize low profits may show different earnings management patterns from those that realize high profits. Prior studies (Balsam, Haw \& Lilien, 1995; DeFond \& Park, 1997; Doyle, Ge \& McVay, 2007) report that firms realizing low earnings are likely to have greater incentives to engage in earnings management to report good earnings performance to investors and creditors than those realizing high earnings. Thus, a negative direction is expected.

Fifth, we include $B I G 4$ variable which takes the value of 1 if a firm is audited by a big audit firm, and 0 otherwise to control for the effect of audit on earnings management. The level of earnings management may differ if a firm is audited by big audit firms (Becker, DeFond Jiambalvo \& Subramanyam, 1998; Francis, Maydew \& Sparks, 1999). Prior studies document that firms audited by big audit firms are less likely to be involved by ABEM than firms audited by smaller audit firms (DeFond \& Subramanyam, 1998). Big auditors tend to conduct a stricter audit to mitigate litigation risk (DeAngelo, 1981; Dye, 1993) and maintain its brand value (DeAngelo, 1981) than non-big audit firms. Thus, a negative sign is predicted for the coefficient of BIG4.

Sixth, LEVERAGE and EQUITY are included as control variables. Prior studies reports that higher leverage is related to lower earnings quality because firms try to avoid violations of debt covenants in financial distress (Dechow et al., 2010). Similarly when firms finance money from a bank or stock investors in the capital market, they have incentives to engage in earnings management to finance capital at lower cost by showing good performance results (Teoh, Welch \& Wong, 1998; Kim \& Park, 2005). Thus, positive signs are expected for the coefficients of LEVERAGE and EQUITY.

Seventh, GOVERNANCE variable is included in the regression model because prior studies consistently show that internal control procedures are negatively related to earnings management (Ashbaugh-Skaife et al., 2007; Doyle et al., 2007; Cho \& Chun, 2016). Good internal control system is known to be a key characteristic of firms having a sound governance structure. We thus expect a negative sign for the coefficient of GOVERNANCE variable.

Eighth, we include the age of a firm, FIRM_AGE, as a control variable because prior studies show that earnings management may differ with changes in firm life cycle (Anthony \& Ramesh, 1992) and use firm age as a control variable in earnings quality studies (Myers, Myers \& Omer, 2003; Kim et al., 2012). (Kim et al., 2012) show negative relationship between earnings management and firm age. In contrast, Myers et al. (2003) report no significant relationship between the two variables. Hence, we do not predict a sign for the coefficient of FIRM_AGE.

Lastly, we employ Industry dummy variables to capture characteristics of KSIC (Korea Standard Industry Classification) two-digit industry (Waddock \& Graves, 1997; Strike. Gao \& Bansal, 2006; Kook \& Kang, 2011). We also use Year dummy to capture the effect of changes in economic conditions during the sample period on RAEM (Lien \& Li, 2013).

\section{EMPIRICAL RESULTS}

\subsection{Descriptive Statistics}

Table 3 shows the descriptive statistics for selected variables of full sample (Panel A), differentiation strategy versus cost leadership strategy groups (Panel B), and correlation coefficients among selected variables (Panel C). We winsorize all continuous variables except $A D J C S R$ at the level of $1^{\text {st }}$ and $99^{\text {th }}$ percentile of the distribution to mitigate the effect of outliers on dependent variables. In Panel A for the full sample, the mean for the level of RAEM (COMB_RM) is -0.036 . The mean of $A D J_{-} C S R$ is 3.146 , which is the natural logarithm of adjusted CSR 
score. The mean of $A D J C S R * D I F F$, the variable of interest included to test the moderating effect of CSR on the relationship between a firm's product strategy and RAEM, is 1.652 .

Turning to the control variables, the mean of $A B S \_D A$ is 0.053 . The mean of SIZE is 26.568 (US\$342 million), implying that the full sample consists of relatively large firms in Korea. The means of sales growth rate (GROWTH), financial leverage (LEVERAGE), and industry mean adjusted ROA (ADJ_ROA) are 12.2 percent, 39.6 percent, and 2.2 percent, respectively. These figures indicate that sample firms on the average have high sales growth rate, a sound capital structure, and good profitability. The profitability seems to be relatively good as compared to their peer firms in the same two-digit KSIC (Korea Standard Industry Classification) industry. Given that sample firms are listed firms performing CSR activities, the validity of mean in the sample appears to be reasonable. The mean of $B I G 4$ is 0.666 , which means that big four audit firms in Korea audit 67 percent of the sample firms. The mean of EQUITY is 15.2 percent, which means that 15.2 percent of the sample firms raised additional capital from their stock investors. Lastly, the mean of natural logarithm of FIRM_AGE is 3.579, indicating that firms have a long history of 35.8 years since their establishment.

Table 3, Panel B provides the comparative descriptive statistics for the differentiation strategy group and the cost leadership strategy group. We observe that the mean and median of $C O M B_{-} R M$ of differentiation group (cost leadership group) are -0.112 and -0.094 (0.046 and 0.032$)$ respectively. The differences of the mean and median of $C O M B_{-} R M$ between the two groups are significant $(\mathrm{p}<0.001)$. This result indicates that differentiation group is less likely to engage in RAEM, and is in line with our conjecture that $D I F F$ is significantly negatively correlated with COMB_RM ( $\rho=0.325, \mathrm{p}<0.01$ as shown in Panel C of Table 3) The mean ADJ_CSR of the differentiation group (the cost leadership group) is 3.202 (3.085), and the difference between the two groups is significant $(\mathrm{p}<0.001)$. This result indicates that differentiation strategy is positively associated with CSR activities as predicted ( $\rho=0.533$, $\mathrm{p}<0.01$ as presented in Panel C) in that CSR strategy is closely associated with a differentiation strategy because one of the primary benefits of CSR activities is the enhancement of the firm image and brand as mentioned before.

Turning to the control variables, we observe that firms with differentiation strategy compared to the firms with cost leadership strategy are of larger size (SIZE) (26.718 (US\$401 million) versus 26.409 (US\$295 million)), have better profitability ( $\left.A D J \_R O A\right)$ ( 2.7 versus 1.6 percent), tend to be audited by big 4 audit firms ( 72.1 versus 60.8 percent), are more likely to raise capital from stock investors (19.7 versus 10.3 percent) and have a better governance structure (4.795 versus 4.639 ); the differences between two groups are all statistically significantly at least at the 5 percent significance level. However, we find a statistically insignificant difference between two groups for the variables of growth rates (GROWTH), leverage (LEVERAGE), and firm age (FIRM_AGE).

Table 3, Panel C reports the Pearson's correlation coefficients on selected variables. $C O M B \_R M$ is significantly negatively correlated with $A D J C C S R(-0.304, \mathrm{p}<0.01), \operatorname{DIFF}(-0.325, \mathrm{p}<0.01), \operatorname{SIZE}(-0.120$. $\mathrm{p}<0.01), A D J \_R O A(-$ $0.329, \mathrm{p}<0.01), B I G 4(-0.137, \mathrm{p}<0.01)$, and GOVERNANCE $(-0.259, \mathrm{p}<0.01)$. We find that the correlation on between $A D J C S R$ and $D I F F$ are $0.533(\mathrm{p}<0.01)$, higher than 0.5 . In addition, the correlation coefficient between GOVERNANCE $\bar{C}$ and ADJ_CSR is $0.502(\mathrm{p}<0.01)$, and the correlation coefficients between GOVERNANCE and SIZE is $0.587(\mathrm{p}<0.01)$. In case the correlation coefficients are larger than 0.5 , we need to check the possibility of multicollinearity problem. The variation inflation factors (VIF) shows that the multicollinearity among independent variables does not present a serious problem. 
Table 3. Descriptive Statistics

\begin{tabular}{|c|c|c|c|c|c|c|}
\hline \multicolumn{7}{|c|}{ Panel A: Full Sample } \\
\hline & $\mathbf{n}$ & Mean & Median & Std. Dev. & $\begin{array}{c}\text { 25th } \\
\text { Percentile }\end{array}$ & $\begin{array}{c}\text { 75th } \\
\text { Percentile }\end{array}$ \\
\hline \multicolumn{7}{|c|}{ Dependent Variables } \\
\hline$C O M B \_R M$ & 659 & -0.036 & -0.024 & 0.243 & -0.172 & 0.101 \\
\hline \multicolumn{7}{|c|}{ Variable of Interest } \\
\hline$A D J \_C S R$ & 659 & 3.146 & 3.150 & 0.110 & 3.068 & 3.229 \\
\hline$D I F \bar{F}$ & 659 & 0.516 & 1.000 & 0.500 & 0.000 & 1.000 \\
\hline$A D J \_C S R * D I F F$ & 659 & 1.652 & 3.026 & 1.603 & 0.000 & 3.213 \\
\hline \multicolumn{7}{|l|}{ Control Variables } \\
\hline$A B S \_D A$ & 659 & 0.053 & 0.039 & 0.049 & 0.018 & 0.073 \\
\hline$S I Z \bar{E}$ & 659 & 26.568 & 26.352 & 1.313 & 25.607 & 27.279 \\
\hline GROWTH & 659 & 0.122 & 0.102 & 0.133 & 0.049 & 0.165 \\
\hline$A D J \_R O A$ & 659 & 0.022 & 0.016 & 0.058 & -0.013 & 0.056 \\
\hline$B I G \overline{4}$ & 659 & 0.666 & 1.000 & 0.472 & 0.000 & 1.000 \\
\hline LEVERAGE & 659 & 0.396 & 0.414 & 0.160 & 0.276 & 0.530 \\
\hline$E O$ & 659 & 0.152 & 0.000 & 0.359 & 0.000 & 0.000 \\
\hline GOVERNANCE & 659 & 4.720 & 4.700 & 0.204 & 4.585 & 4.820 \\
\hline FIRM $A G E$ & 659 & 3.579 & 3.664 & 0.525 & 3.434 & 3.912 \\
\hline
\end{tabular}

Panel B: Descriptive Statistics by Differentiation versus Cost strategy

\begin{tabular}{l|c|c|c|c|c|c|c|c}
\hline & \multicolumn{2}{c|}{ Differentiation Group } & \multicolumn{2}{c|}{ Cost Leadership Group } & \multicolumn{2}{c}{ Difference test: p-value } \\
& $\mathbf{n}$ & $\mathbf{M e a n}$ & $\mathbf{M e d i a n}$ & $\mathbf{n}$ & $\mathbf{M e a n}$ & $\mathbf{M e d i a n}$ & \multicolumn{1}{c}{ t-test } & Wilcoxon test \\
\hline COMB_RM & 340 & -0.112 & -0.094 & 319 & 0.046 & 0.032 & $<0.001$ & $<0.001$ \\
\hline ADJ_CSR & 340 & 3.2023 & 3.2086 & 319 & 3.0852 & 3.0839 & $<0.001$ & $<0.001$ \\
\hline ABS_DA & 340 & 0.050 & 0.039 & 319 & 0.056 & 0.039 & 0.083 & 0.554 \\
\hline SIZE & 340 & 26.718 & 26.374 & 319 & 26.409 & 26.294 & 0.002 & 0.054 \\
\hline GROWTH & 340 & 0.115 & 0.095 & 319 & 0.129 & 0.117 & 0.204 & 0.033 \\
\hline ADJ_ROA & 340 & 0.027 & 0.025 & 319 & 0.016 & 0.007 & 0.019 & $<0.001$ \\
\hline BIG_ & 340 & 0.721 & 1.000 & 319 & 0.608 & 1.000 & 0.002 & 0.002 \\
\hline LEVERAGE & 340 & 0.387 & 0.399 & 319 & 0.406 & 0.425 & 0.143 & 0.106 \\
\hline EO & 340 & 0.197 & 0.000 & 319 & 0.103 & 0.000 & $<0.001$ & $<0.001$ \\
\hline GOVERNANCE & 340 & 4.795 & 4.754 & 319 & 4.639 & 4.644 & $<0.001$ & $<0.001$ \\
\hline FIRM_AGE & 340 & 3.585 & 3.749 & 319 & 3.573 & 3.611 & 0.763 & $<0.001$ \\
\hline
\end{tabular}

Panel C: Correlation Coefficients among Selected Variables

\begin{tabular}{|c|c|c|c|c|c|c|c|}
\hline & & 1 & 2 & 3 & 4 & 5 & 6 \\
\hline 1. & $C O M B \_R M$ & 1.000 & & & & & \\
\hline 2. & $A D J \_\overline{C S R}$ & $-0.304^{* *}$ & 1.000 & & & & \\
\hline 3. & $D I F \bar{F}$ & $-0.325^{* *}$ & $0.533^{* *}$ & 1.000 & & & \\
\hline 4. & $A B S \_D A$ & 0.019 & $-0.101^{* *}$ & -0.068 & 1.000 & & \\
\hline 5. & $S I Z \bar{E}$ & $-0.120^{* *}$ & $0.395^{* *}$ & $0.118^{* *}$ & -0.014 & 1.000 & \\
\hline 6. & GROWTH & -0.065 & 0.002 & -0.050 & $0.165^{* *}$ & $0.093^{*}$ & 1.000 \\
\hline 7. & $A D J \_R O A$ & $-0.329^{* *}$ & $0.118^{* *}$ & $0.092^{*}$ & $0.128^{* *}$ & $0.122^{* *}$ & $0.183^{* *}$ \\
\hline 8. & $B I G \overline{4}$ & $-0.137^{* *}$ & $0.253^{* *}$ & $0.119^{* *}$ & -0.048 & $0.374^{* *}$ & 0.003 \\
\hline 9. & LEVERAGE & 0.074 & 0.038 & -0.057 & 0.070 & $0.267^{* *}$ & $0.124^{* *}$ \\
\hline 10. & $E O$ & -0.036 & $0.103^{* *}$ & $0.130^{* *}$ & -0.031 & -0.014 & $0.090^{*}$ \\
\hline 11. & GOVERNANCE & $-0.259^{* *}$ & $0.502^{* *}$ & $0.383^{* *}$ & -0.006 & $0.587^{* *}$ & 0.008 \\
\hline \multirow[t]{2}{*}{12.} & $F I R M \_A G E$ & $0.174^{* *}$ & -0.066 & 0.012 & $-0.086^{*}$ & 0.022 & $-0.224^{* *}$ \\
\hline & $\mathrm{n}$ & 659 & 659 & 659 & 659 & 659 & 659 \\
\hline
\end{tabular}

(Table 3, Panel C continued on next page) 


\begin{tabular}{|c|c|c|c|c|c|c|c|}
\hline & & 7 & 8 & 9 & 10 & 11 & 12 \\
\hline 7. & $A D J R O A$ & 1 & & & & & \\
\hline 8. & $B I G \overline{4}$ & $0.086^{*}$ & 1.000 & & & & \\
\hline 9. & LEVERAGE & $-0.286^{* *}$ & $0.133^{* *}$ & 1.000 & & & \\
\hline 10. & $E O$ & 0.000 & 0.030 & $0.094^{*}$ & 1.000 & & \\
\hline 11. & GOVERNANCE & $0.155^{* *}$ & $0.252^{* *}$ & 0.064 & -0.020 & 1.000 & \\
\hline \multirow[t]{2}{*}{12.} & FIRM_AGE & $-0.095^{*}$ & 0.004 & $-0.123^{* *}$ & 0.071 & $-0.079^{*}$ & 1.000 \\
\hline & $\mathrm{n}$ & 659 & 659 & 659 & 659 & 659 & 659 \\
\hline
\end{tabular}

The Pearson correlation coefficients are presented below the diagonal. * ** indicate significance at 5 percent and 1 percent levels, respectively. Variables are defined in Appendix A.

\subsection{Regression Analysis}

Table 4 reports the results of the regression analyzes. We use $C O M B_{-} R M$ as the dependent variable to measure a firm's level of RAEM. Empirical results for Models 2 and 3 show that $D I F F$ variable is significantly and negatively associated with $C O M B \_R M(-0.226, \mathrm{p}, 0.01$ for model 2 and $-0.205, \mathrm{p}<0.01$ for model 3$)$, indicating that firms pursuing the differentiation strategy are less likely to manage earnings using RAEM compared to those pursuing the cost leadership strategy. Our finding supports the first hypothesis (H1). The Differentiation strategy emphasizes brand image enhancement and innovative production by investing into large portions of R\&D and advertisement expenditure to sales revenues. Thus, firms pursuing a differentiation strategy have an incentive not to reduce selling and administrative expenses including R\&D and advertisement expenditure, which is one of the main means of RAEM. Thus, the evidence of this study lends support to the arguments that firm's operational (Beneish, 1997), investment or production decision (Schipper, 1989), or types of product (Lev, 1983) may influence earnings management. Moreover, Models 1 and 3 of Table 4 indicate that CSR activities (ADJ_CSR) are significantly and negatively associated with RAEM (COMB_RM), consistent with prior studies (Kim et al., 2012; Lim \& Choi, 2013; Cho \& Chun, 2016).

In Model 4 of Table4, the interactive term variable, $A D J C S R^{*} D I F F$, shows the interaction effect between differentiation strategy and CSR activities on the level of RAEM. The estimated coefficient on ADJ_CSR*DIFF variable is negative and significant $(-0.380, \mathrm{p}<0.05)$. This finding is consistent with the second hypothesis $(H 2)$ that the CSR activities as a moderating factor strengthen the negative relationship between the differentiation strategy and RAEM.

For the control variables of Model 4 in Table $4^{\text {iv }}$, the coefficients of SIZE and FIRM_AGE are significantly positive ( 0.021 and $0.054, p<0.05$ and $\mathrm{p}<0.05$, respectively). These results imply that larger and older firms tend to engage in RAEM. However, the coefficients of $A D J R O A$ and GOVERNANCE are significantly negative $(-1.044$ and -0.099 , $\mathrm{p}<0.01$ and $\mathrm{p}<0.10)$ as expected. This result indicates that profitable firms are less engaged in RAEM because of low incentives to manipulate earnings to present good performance to the capital market. Moreover, firms having a good governance structure seem to constrain RAEM effectively by monitoring manager's opportunistic reporting behavior. Meanwhile, the adjusted $\mathrm{R}^{2}$ in the models are larger than 0.28 . This value provides an indication of reasonable explanatory powers for the regression model to test the hypothesis. 
Table 4. Multiple Regressions of COMB RM on $A D J C S R$ and DIFF

\begin{tabular}{|c|c|c|c|c|c|}
\hline \multirow{3}{*}{ Independent variables } & \multirow{3}{*}{$\begin{array}{c}\text { Predicted } \\
\text { Sign }\end{array}$} & \multicolumn{4}{|c|}{ Dependent variable } \\
\hline & & Model 1 & Model 2 & Model 3 & Model 4 \\
\hline & & $\underset{\text { (t-stat) }}{C O M B \_R M \text { Coeff. }}$ & $\underset{\text { (t-stat) }}{C O M B \_R M \text { Coeff. }}$ & $\underset{\substack{\text { (t-stat) } \\
C O M B R R}}{C \text { Coeff. }}$ & $\underset{\text { (t-stat) }}{C O M B \_R M \text { Coeff. }}$ \\
\hline \multirow{2}{*}{$A D J+C S R$} & \multirow{2}{*}{-} & $-0.563^{* * *}$ & & $-0.322^{* * *}$ & -0.138 \\
\hline & & $(-5.31)$ & & $(-3.22)$ & $(-1.22)$ \\
\hline \multirow{2}{*}{ DIFF (H1) } & \multirow[b]{2}{*}{-} & & $-0.226^{* * *}$ & $-0.205^{* * *}$ & $0.991^{*}$ \\
\hline & & & $(-10.00)$ & $(-9.05)$ & $(1.65)$ \\
\hline \multirow{2}{*}{$A D J \_C S R * D I F F(H 2)$} & \multirow[b]{2}{*}{-} & & & & -0.380 ** \\
\hline & & & & & $(-2.00)$ \\
\hline \multirow{2}{*}{$A B S \_D A$} & \multirow{2}{*}{$?$} & 0.184 & 0.176 & 0.145 & 0.145 \\
\hline & & $(0.76)$ & $(0.73)$ & $(0.61)$ & $(0.61)$ \\
\hline \multirow{2}{*}{ SIZE } & \multirow{2}{*}{$?$} & $0.022^{* *}$ & $0.014^{*}$ & $0.021^{* *}$ & $0.021^{* *}$ \\
\hline & & $(2.45)$ & $(1.67)$ & $(2.38)$ & $(2.39)$ \\
\hline \multirow{2}{*}{ GROWTH } & \multirow{2}{*}{$?$} & 0.044 & 0.017 & 0.006 & 0.010 \\
\hline & & $(0.42)$ & $(0.18)$ & $(0.06)$ & $(0.10)$ \\
\hline \multirow{2}{*}{$A D J \_R O A$} & \multirow[b]{2}{*}{ - } & $-1.129^{* * *}$ & $-1.080^{* * *}$ & $-1.065^{* * *}$ & $-1.044^{* * *}$ \\
\hline & & $(-5.88)$ & $(-6.02)$ & $(-5.91)$ & $(-5.82)$ \\
\hline \multirow{2}{*}{$B I G 4$} & \multirow{2}{*}{-} & -0.012 & -0.012 & -0.007 & -0.004 \\
\hline & & $(-0.65)$ & $(-0.73)$ & $(-0.43)$ & $(-0.25)$ \\
\hline \multirow{2}{*}{ LEVERAGE } & \multirow{2}{*}{+} & 0.048 & 0.051 & 0.064 & 0.057 \\
\hline & & $(0.74)$ & $(0.84)$ & $(1.06)$ & $(0.94)$ \\
\hline \multirow{2}{*}{$E Q U I T Y$} & \multirow{2}{*}{+} & -0.016 & -0.016 & -0.016 & -0.014 \\
\hline & & $(-0.75)$ & $(-0.76)$ & $(-0.75)$ & $(-0.67)$ \\
\hline \multirow{2}{*}{ GOVERNANCE } & \multirow{2}{*}{-} & $-0.172^{* * *}$ & $-0.134^{* *}$ & $-0.103^{*}$ & $-0.099^{*}$ \\
\hline & & $(-3.02)$ & $(-2.52)$ & $(-1.93)$ & $(-1.84)$ \\
\hline \multirow{2}{*}{ FIRM_AGE } & \multirow{2}{*}{$?$} & $0.058^{* *}$ & $0.063^{* *}$ & $0.057^{* *}$ & $0.054^{* *}$ \\
\hline & & $(2.23)_{* * *}$ & $(2.51)$ & $(2.32)$ & $(2.25)$ \\
\hline \multirow{2}{*}{ CONSTANT } & & $1.748^{* * *}$ & 0.118 & $0.817^{* * *}$ & 0.238 \\
\hline & & $(5.96)$ & $(0.54)$ & $(2.72)$ & $(0.68)$ \\
\hline Industry dummies & & Included & Included & Included & Included \\
\hline Year dummies & & Included & Included & Included & Included \\
\hline Mean of VIF & & 1.95 & 1.97 & 2.00 & n.a. \\
\hline Adj. $\mathrm{R}^{2}$ & & 0.28 & 0.34 & 0.35 & 0.35 \\
\hline $\mathrm{F}$ & & $10.93^{* * *}$ & $18.95^{* * *}$ & $18.08^{* * *}$ & $17.86^{* * *}$ \\
\hline $\mathrm{n}$ & 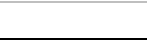 & 659 & 659 & 659 & 659 \\
\hline
\end{tabular}

In Table 5, Models 1 and 2 show the result of the multivariate regression analysis using $A B \_E X P$, an individual component of $C O M B_{-} R M$. In this study, we use $N E G A_{-} A B_{-} E X P\left(=(-1) * A B \_E X P\right)$ variable to make the same direction of coefficient as $C O M B_{-} R M$, leading to easy interpretation of the result. Model 1 in Table 5 shows that $D I F F$ is significantly and negatively related to NEGA_AB_EXP $(-0.082, \mathrm{p}<0.01)$ as predicted, supporting the hypothesis (H1). Model 2 shows that the moderating variable, $A D J C S R * D I F F$, is significantly and negatively associated with NEGA_EXP $(-0.200, \mathrm{p}<0.05)$ as expected, supporting the hypothesis (H2). Models 3 and 4 use $A B_{-} P R O D$ as the dependent variable and the results show that the DIFF and $A D J C S R * D I F F$ are also significantly and negatively associated with $A B_{-} P R O D$ as predicted $(-0.095, \mathrm{p}<0.01 ;-0.214, \mathrm{p}<0.05$, respectively), supporting the hypotheses ( $\mathrm{H1}$ and $\mathrm{H} 2$ ). Table 5, Model 5 provides the result of the multivariate regression analysis using $A B_{-} C F O$. We use $N E G A_{-} A B_{-} C F O\left(=(-1) * A B_{-} C F O\right)$ variable to make the same direction of coefficient as $C O M B \_R M$, leading to easy interpretation of the result. The result reveals that DIFF is significantly and negatively associated with $N E G A \_A B \_C F O(-0.025, \mathrm{p}<0.01)$, supporting the hypothesis (H1). These findings reveal that firms pursuing the differentiation strategy and active CSR activities are more likely to constrain RAEM to implement their firm's differentiation strategy as compared to firms adopting cost leadership strategy. However, ADJ_CSR*DIFF is 
not significantly related to $N E G A \_A B \_C F O\left(=(-1) * A B \_C F O\right)$ variable $(0.012$, (t-stat: 0.19$)$, not supporting the hypothesis (H2). It is not surprising to have an insignificant coefficient because the net effect of CFO seems ambiguous. This ambiguous result is likely to come from the mixed effect of cash flow by price discount (negative), overproduction (negative) and cutting discretionary expenditures (positive) (Roychowdhury, 2006; Zang, 2012, p. $682)$.

Taken together, empirical results support the argument that firms pursuing the differentiation strategy manage their earnings using REAM less than those pursuing the cost leadership strategy. Further, active CSR firms strengthen the negative relationship between differentiation strategy and RAEM, consistent with the contention that CSR is a popular means of implementing the differentiation strategy (McWilliams \& Siegel, 2001; McWilliams et al., 2006).

Table 5. Multiple Regressions of COMB RM Components on DIFF and ADJ CSR*DIFF

\begin{tabular}{|c|c|c|c|c|c|c|c|}
\hline \multirow{3}{*}{$\begin{array}{l}\text { Independent } \\
\text { variables }\end{array}$} & \multirow{3}{*}{$\begin{array}{l}\text { Pred. } \\
\text { Sign }\end{array}$} & \multicolumn{6}{|c|}{ Dependent variable } \\
\hline & & Model 1 & Model 2 & Model 3 & Model 4 & Model 5 & Model 6 \\
\hline & & $\begin{array}{c}N E G A \_A B \\
E X P \text { Coeff. } \\
\text { (t-stat) }\end{array}$ & $\begin{array}{c}N E G A A_{-} B_{-} \\
E X P \text { Coeff. } \\
\text { (t-stat) }\end{array}$ & $\begin{array}{c}A B \_P R O D \\
\text { Coeff. } \\
\text { (t-stat) }\end{array}$ & $\begin{array}{c}A B \_P R O D \\
\text { Coeff. } \\
\text { (t-stat) }\end{array}$ & $\begin{array}{c}N E G A \_A B- \\
C F O \text { Coeff. } \\
\text { (t-stat) }\end{array}$ & $\begin{array}{c}N E G A \_A B \\
C F O \text { Coeff. } \\
\text { (t-stat) }\end{array}$ \\
\hline \multirow{2}{*}{$A D J \_C S R$} & \multirow{2}{*}{-} & $-0.187^{* * *}$ & $-0.091^{* *}$ & $-0.180^{* * *}$ & -0.076 & 0.037 & 0.032 \\
\hline & & $(-4.45)$ & $(-2.06)$ & $(-3.66)$ & $(-1.35)$ & $(1.00)$ & $(0.68)$ \\
\hline \multirow{2}{*}{$\operatorname{DIFF}(H 1)$} & \multirow{2}{*}{-} & $-0.082^{* * *}$ & $0.546^{* *}$ & $-0.095^{* * *}$ & $0.580^{* *}$ & $-0.025^{* * *}$ & -0.063 \\
\hline & & $(-9.15)$ & $(2.14)$ & $(-8.74)$ & $(2.01)$ & $(-2.96)$ & $(-0.32)$ \\
\hline \multirow{2}{*}{$\begin{array}{l}A D J C C S R * D I F F \\
(\mathrm{H} 2)\end{array}$} & \multirow{2}{*}{-} & & $-0.200^{* *}$ & & $-0.214^{* *}$ & & 0.012 \\
\hline & & & $(-2.46)$ & & $(-2.34)$ & & $(0.19)$ \\
\hline \multirow{2}{*}{$A B S \_D A$} & \multirow{2}{*}{$?$} & 0.001 & 0.001 & 0.062 & 0.062 & 0.039 & 0.039 \\
\hline & & $(0.01)$ & $(0.01)$ & $(0.59)$ & $(0.59)$ & $(0.37)$ & $(0.37)$ \\
\hline \multirow{2}{*}{ SIZE } & \multirow{2}{*}{$?$} & $0.019^{* * *}$ & $0.019^{* * *}$ & $0.012^{* * *}$ & $0.012^{* * *}$ & $-0.009^{* * *}$ & $-0.009^{* * *}$ \\
\hline & & $(4.93)$ & $(4.98)$ & $(2.81)$ & $(2.83)$ & $(-2.89)$ & $(-2.88)$ \\
\hline \multirow{2}{*}{ GROWTH } & \multirow{2}{*}{$?$} & -0.030 & -0.027 & 0.032 & 0.034 & -0.016 & -0.016 \\
\hline & & $(-0.67)$ & $(-0.62)$ & $(0.63)$ & $(0.67)$ & $(-0.56)$ & $(-0.56)$ \\
\hline \multirow{2}{*}{$A D J \_R O A$} & \multirow{2}{*}{-} & $-0.129^{*}$ & $-0.118^{*}$ & $-0.513^{* * *}$ & $-0.501^{* * *}$ & $-0.409^{* * *}$ & $-0.409^{* * *}$ \\
\hline & & $(-1.81)$ & $(-1.68)$ & $(-5.94)$ & $(-5.83)$ & $(-6.10)$ & $(-6.09)$ \\
\hline \multirow{2}{*}{$B I G 4$} & \multirow{2}{*}{-} & $-0.013^{*}$ & $-0.012^{*}$ & 0.003 & 0.005 & 0.002 & 0.002 \\
\hline & & $(-1.95)$ & $(-1.72)$ & $(0.38)$ & $(0.58)$ & $(0.33)$ & $(0.31)$ \\
\hline \multirow{2}{*}{ LEVERAGE } & \multirow{2}{*}{+} & -0.030 & -0.034 & 0.018 & 0.014 & $0.077^{* * *}$ & $0.077^{* * *}$ \\
\hline & & $(-1.16)$ & $(-1.32)$ & $(0.60)$ & $(0.47)$ & $(3.86)$ & $(3.86)$ \\
\hline \multirow{2}{*}{ EQUITY } & \multirow{2}{*}{+} & -0.012 & -0.012 & -0.005 & -0.004 & 0.002 & 0.002 \\
\hline & & $(-1.41)$ & $(-1.33)$ & $(-0.52)$ & $(-0.43)$ & $(0.28)$ & $(0.27)$ \\
\hline \multirow{2}{*}{ GOVERNANCE } & \multirow[b]{2}{*}{-} & $-0.040^{*}$ & -0.037 & $-0.044^{*}$ & -0.041 & -0.018 & -0.018 \\
\hline & & $(-1.71)$ & $(-1.60)$ & $(-1.68)$ & $(-1.58)$ & $(-0.96)$ & $(-0.97)$ \\
\hline \multirow{2}{*}{ FIRM_AGE } & \multirow{2}{*}{$?$} & $0.025^{* *}$ & $0.023^{* *}$ & $0.033^{* * *}$ & $0.031^{* * *}$ & -0.000 & -0.000 \\
\hline & & $(2.18)$ & $(2.11)$ & $(2.73)$ & $(2.67)$ & $(-0.05)$ & $(-0.03)$ \\
\hline \multirow{2}{*}{ CONSTANT } & & $0.272^{* *}$ & -0.033 & $0.373^{* *}$ & 0.046 & $0.188^{*}$ & 0.207 \\
\hline & & $(2.13)$ & $(-0.23)$ & $(2.52)$ & $(0.26)$ & $(1.83)$ & $(1.55)$ \\
\hline $\begin{array}{l}\text { Industry } \\
\text { dummies }\end{array}$ & & Included & Included & Included & Included & Included & Included \\
\hline Year dummies & & Included & Included & Included & Included & Included & Included \\
\hline Mean of VIF & & 2.00 & n.a. & 2.00 & n.a. & 2.00 & n.a. \\
\hline Adjusted $\mathrm{R}^{2}$ & & 0.31 & 0.32 & 0.33 & 0.33 & 0.21 & 0.21 \\
\hline $\mathrm{F}$ & & $14.28^{* * *}$ & $13.92^{* * *}$ & $16.70^{* * *}$ & $17.99^{* * *}$ & $6.89^{* * *}$ & $6.66^{* * *}$ \\
\hline $\mathrm{n}$ & & 659 & 659 & 659 & 659 & 659 & 659 \\
\hline
\end{tabular}




\subsection{Additional Tests}

\subsubsection{Other RAEM Measures}

We employ different approaches to measure RAEM following prior studies. Zang (2012, p. 682) employs COMP_EXP_PROD to exclude the $A B \_C F O$ effect because $A B \_C F O$ is likely to be ambiguous due to different cash flow transaction. Cohen et al. (2008) use COMB_RM_STD, a combination of the standardized value of three components, to mitigate the scale effect of any one of three individual components of $C O M B \_R M$. Hence, we perform regression analysis to confirm construct validity for $C O M B \_R M$. As shown in Table 6, Models 1 and 2 , we use $C O M P{ }_{-} E X P_{-} P R O D$ as the dependent variable instead of $C O M B_{-} R M$. The results are in line with those in Table 4, supporting the hypotheses (H1 and H2). Specifically, DIFF and $\overline{A D} J$ CSR $* D I F F$ are significantly and negatively associated with $C O M B \_E X P \_P R O D(-0.181, \mathrm{p}<0.01 ;-0.404, \mathrm{p}<0.05$, respectively). In Models 3 and 4 , We also use $C O M B \_R M \_S T D$ as the dependent variable instead of $C O M B \_R M$. The results are consistent with those in Table 4, supporting the hypotheses (H1 and H2). Specifically, DIFF and ADJ_CSR*DIFF is significantly and negatively associated with $C O M B \_R M \_S T D(-1.814, \mathrm{p}<0.01 ;-2.979, \mathrm{p}<0.10$, respectively). We thus conclude that the results in Table 4 remain robust after we perform sensitivity tests.

Table 6. Multiple Regressions of Other Measures of RAEM on DIFF and ADJ CSR*DIFF

\begin{tabular}{|c|c|c|c|c|c|}
\hline \multirow[b]{3}{*}{$\begin{array}{l}\text { Independent } \\
\text { variables }\end{array}$} & \multirow{3}{*}{$\begin{array}{l}\text { Predicted } \\
\text { Sign }\end{array}$} & \multicolumn{4}{|c|}{ Dependent variable } \\
\hline & & Model 1 & Model 2 & Model 3 & Model 4 \\
\hline & & $\begin{array}{c}\text { COMB_EXP_PROD } \\
\begin{array}{c}\text { Coefficient } \\
\text { (t-stat) }\end{array}\end{array}$ & $\begin{array}{c}\text { COMB_EXP_PROD } \\
\begin{array}{c}\text { Coefficient } \\
\text { (t-stat) }\end{array} \\
\end{array}$ & $\begin{array}{c}C O M B \_R M \_S T D \\
\text { Coefficient } \\
\text { (t-stat) }\end{array}$ & $\begin{array}{c}C O M B \_R M \_S T D \\
\text { Coefficient } \\
\text { (t-stat) }\end{array}$ \\
\hline \multirow{2}{*}{$A D J \_C S R$} & \multirow{2}{*}{ - } & $-0.367^{* * *}$ & $-0.171^{*}$ & $-2.495^{* * *}$ & -1.053 \\
\hline & & $(-4.25)$ & $(-1.89)$ & $(-2.71)$ & $(-0.99)$ \\
\hline \multirow{2}{*}{ DIFF (H1) } & \multirow{2}{*}{ - } & $-0.181^{* * *}$ & $1.090^{* *}$ & $-1.814^{* * * *}$ & 7.566 \\
\hline & & $(-9.61)$ & $(2.08)$ & $(-8.67)$ & $(1.39)$ \\
\hline \multirow{2}{*}{$\begin{array}{l}\text { ADJ_CSR*DIFF } \\
(\mathrm{H} 2)\end{array}$} & \multirow{2}{*}{-} & & $-0.404^{* * *}$ & & $-2.979^{*}$ \\
\hline & & & $(-2.43)$ & & $(-1.73)$ \\
\hline \multirow{2}{*}{$A B S \_D A$} & \multirow{2}{*}{$?$} & 0.090 & 0.090 & 1.444 & 1.442 \\
\hline & & $(0.50)$ & $(0.50)$ & $(0.63)$ & $(0.63)$ \\
\hline \multirow{2}{*}{ SIZE } & \multirow{2}{*}{$?$} & $0.030^{* * *}$ & $0.030^{* * *}$ & $0.139 *$ & $0.138^{*}$ \\
\hline & & $(3.97)$ & $(4.01)$ & $(1.73)$ & $(1.72)$ \\
\hline \multirow{2}{*}{ GROWTH } & \multirow{2}{*}{$?$} & 0.011 & 0.015 & 0.009 & 0.040 \\
\hline & & $(0.12)$ & $(0.16)$ & $(0.01)$ & $(0.05)$ \\
\hline \multirow{2}{*}{$A D J \_R O A$} & \multirow{2}{*}{-} & $-0.652^{* * *}$ & $-0.629^{* * *}$ & $-10.340^{* * *}$ & $-10.171^{* * *}$ \\
\hline & & $(-4.46)$ & $(-4.35)$ & $(-6.17)$ & $(-6.08)$ \\
\hline \multirow{2}{*}{$B I G 4$} & \multirow{2}{*}{ - } & -0.008 & -0.005 & -0.058 & -0.035 \\
\hline & & $(-0.59)$ & $(-0.37)$ & $(-0.38)$ & $(-0.23)$ \\
\hline \multirow{2}{*}{ LEVERAGE } & \multirow{2}{*}{+} & -0.008 & -0.015 & 0.811 & 0.755 \\
\hline & & $(-0.14)$ & $(-0.29)$ & $(1.48)$ & $(1.38)$ \\
\hline \multirow{2}{*}{ EQUITY } & \multirow{2}{*}{+} & -0.018 & -0.017 & -0.127 & -0.115 \\
\hline & & $(-1.04)$ & $(-0.96)$ & $(-0.66)$ & $(-0.60)$ \\
\hline \multirow{2}{*}{ GOVERNANCE } & \multirow[b]{2}{*}{ - } & $-0.081^{*}$ & -0.076 & $-0.918^{*}$ & $-0.886^{*}$ \\
\hline & & $(-1.76)$ & $(-1.65)$ & $(-1.88)$ & $(-1.80)$ \\
\hline \multirow{2}{*}{$F I R M \_A G E$} & \multirow{2}{*}{$?$} & $0.058^{* *}$ & $0.055^{* *}$ & $0.458^{* *}$ & $0.431^{* *}$ \\
\hline & & $(2.49)$ & $(2.43)$ & $(2.15)$ & $(2.07)$ \\
\hline \multirow{2}{*}{ CONSTANT } & & $0.648^{* *}$ & 0.033 & $7.716^{* * *}$ & 3.179 \\
\hline & & $(2.49)$ & $(0.11)$ & $(2.82)$ & $(0.98)$ \\
\hline
\end{tabular}

(Table 6 continued on next page) 
(Table 6 continued)

\begin{tabular}{|c|c|c|c|c|c|}
\hline \multirow[b]{3}{*}{$\begin{array}{l}\text { Independent } \\
\text { variables }\end{array}$} & \multirow{3}{*}{$\begin{array}{l}\text { Predicted } \\
\text { Sign }\end{array}$} & \multicolumn{4}{|c|}{ Dependent variable } \\
\hline & & Model 1 & Model 2 & Model 3 & Model 4 \\
\hline & & $\begin{array}{c}\text { COMB_EXP_PROD } \\
\text { Coefficient } \\
\text { (t-stat) }\end{array}$ & $\begin{array}{c}\text { COMB_EXP_PROD } \\
\begin{array}{c}\text { Coefficient } \\
\text { (t-stat) }\end{array}\end{array}$ & $\begin{array}{c}C O M B \_R M \_S T D \\
\text { Coefficient } \\
\text { (t-stat) }\end{array}$ & $\begin{array}{c}C O M B \_R M \_S T D \\
\text { Coefficient } \\
\text { (t-stat) }\end{array}$ \\
\hline Industry dummies & & Included & Included & Included & Included \\
\hline Year dummies & & Included & Included & Included & Included \\
\hline Mean of VIF & & 2.00 & n.a. & 2.00 & n.a. \\
\hline Adjusted $\mathrm{R}^{2}$ & & 0.35 & 0.35 & 0.35 & 0.35 \\
\hline $\mathrm{F}$ & & $17.24^{* * *}$ & $16.43^{* * *}$ & $16.92^{* * *}$ & $16.58^{* * *}$ \\
\hline $\mathrm{n}$ & & 659 & 659 & 659 & 659 \\
\hline
\end{tabular}

\section{Variable Definitions:}

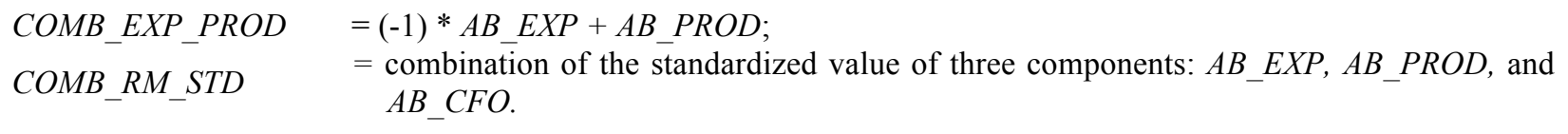

\subsubsection{DIFF_RATIO: Summation of $R \& D$ and advertising Intensity Ratios}

The advantage of employing a dummy variable for differentiation strategy is that by grouping sample firms based on continuous variables we can get away from possible measurement problem of those variables. However if continuous variables measure the characteristics a researcher wants to capture reasonably well, a firm's production strategy in this study, dummy variables may lose a lot of information specific to each firm. To mitigate this matter, we use the sum of $\mathrm{R} \& \mathrm{D}$ and advertising intensity ratios (DIFF_RATIO) as an alternative of $D I F F$, the dummy variable. Table 7 reports that DIFF_RATIO is negatively associated with RAEM, supporting our hypothesis (HI) contending that firms with differentiation strategy investing in the high level of R\&D and advertising expenses manages earnings using real activities less than firms with cost leadership strategy. 
Table 7. Regressions of Measures of RAEM on Sum of R\&D and Advertising Intensity Ratios

\begin{tabular}{|c|c|c|c|c|}
\hline \multirow{3}{*}{$\begin{array}{l}\text { Independent } \\
\text { variables }\end{array}$} & \multirow{3}{*}{$\begin{array}{l}\text { Predicted } \\
\text { Sign }\end{array}$} & \multicolumn{3}{|c|}{ Dependent variable } \\
\hline & & Model 1 & Model 3 & Model 5 \\
\hline & & $\begin{array}{c}C O M B \_R M \text { Coefficient } \\
\text { (t-stat) }\end{array}$ & COMB_EXP_PROD Coeff. & $C O M B \_R M \_S T D$ Coeff. \\
\hline \multirow{2}{*}{$A D J \_C S R$} & \multirow{2}{*}{-} & $-0.211^{* *}$ & $-0.247^{* * *}$ & $-1.620^{*}$ \\
\hline & & $(-2.30)$ & $(-3.23)$ & $(-1.89)$ \\
\hline \multirow{2}{*}{$\begin{array}{l}\text { DIFF_RATIO_SUM } \\
(H 1)\end{array}$} & \multirow{2}{*}{-} & $-5.335^{* * *}$ & $-5.061^{* * *}$ & $-45.730^{* * *}$ \\
\hline & & $(-12.80)$ & $(-12.51)$ & $(-12.87)$ \\
\hline \multirow{2}{*}{$A B S \_D A$} & \multirow{2}{*}{$?$} & -0.002 & -0.052 & 0.193 \\
\hline & & $(-0.01)$ & $(-0.32)$ & $(0.09)$ \\
\hline \multirow{2}{*}{$S I Z E$} & \multirow{2}{*}{$?$} & $0.013^{*}$ & $0.023^{* * *}$ & 0.077 \\
\hline & & $(1.74)$ & $(3.49)$ & $(1.06)$ \\
\hline \multirow{2}{*}{ GROWTH } & \multirow[b]{2}{*}{$?$} & 0.032 & 0.033 & 0.243 \\
\hline & & $(0.36)$ & $(0.40)$ & $(0.31)$ \\
\hline \multirow{2}{*}{$A D J_{-} R O A$} & \multirow{2}{*}{-} & $-0.909^{* * *}$ & $-0.500^{* * *}$ & $-9.019^{* * *}$ \\
\hline & & $(-5.31)$ & $(-3.84)$ & $(-5.57)$ \\
\hline \multirow{2}{*}{$B I G 4$} & \multirow[b]{2}{*}{-} & 0.007 & 0.005 & 0.060 \\
\hline & & $(0.42)$ & $(0.39)$ & $(0.40)$ \\
\hline \multirow{2}{*}{ LEVERAGE } & \multirow{2}{*}{+} & -0.018 & $-0.085^{*}$ & 0.102 \\
\hline & & $(-0.35)$ & $(-1.95)$ & $(0.22)$ \\
\hline \multirow{2}{*}{ EQUITY } & \multirow{2}{*}{+} & -0.002 & -0.006 & -0.014 \\
\hline & & $(-0.12)$ & $(-0.37)$ & $(-0.08)$ \\
\hline \multirow{2}{*}{ GOVERNANCE } & \multirow{2}{*}{-} & -0.005 & 0.017 & -0.097 \\
\hline & & $(-0.11)$ & $(0.48)$ & $(-0.23)$ \\
\hline \multirow{2}{*}{$F I R M \_A G E$} & \multirow{2}{*}{$?$} & 0.026 & $0.029^{*}$ & 0.191 \\
\hline & & $(1.53)$ & $(1.88)$ & $(1.23)$ \\
\hline \multirow{2}{*}{ CONSTANT } & & 0.339 & 0.137 & 3.899 \\
\hline & & $(1.31)$ & $(0.62)$ & $(1.64)$ \\
\hline Industry dummies & & Included & Included & Included \\
\hline Year dummies & & Included & Included & Included \\
\hline Mean of VIF & & 2.05 & 2.05 & 2.05 \\
\hline Adjusted $\mathrm{R}^{2}$ & & 0.49 & 0.52 & 0.47 \\
\hline $\mathrm{F}$ & & $20.39^{* * *}$ & $19.50^{* * *}$ & $19.79^{* * *}$ \\
\hline $\mathrm{n}$ & & 659 & 659 & 659 \\
\hline
\end{tabular}

\section{Variable Definitions:}
$C O M B \_E X P \_P R O D=(-1) * A B \_E X P+A B \_P R O D$
COMB RM_STD $\quad=$ combination of the standardized value of three components: $A B \_E X P, A B \_P R O D$, and $A B \_C F O$.
$=$ Average of 6 years R\&D intensity measured by R\&D expenses / Sales + Average of 6
DIFF_RATIO_SUM years advertisement intensity measured by Advertising expenses / Sales.

\subsubsection{Other RAEM measures on unadjusted CSR score}

The adjusted CSR score $\left(A D J \_C S R\right)$ is more appropriate to mitigate the governance effect of unadjusted CSR score on RAEM when we use the level of corporate governance as a control variable. However, most empirical studies using CSR scores in Korea employ unadjusted CSR scores to proxy for the level of CSR activities. Thus, we use the unadjusted CSR score ( $\left.U N A D J \_C S R\right)$ to investigate the relationship with $C O M B \_R M, C O M B \_E X P \_P R O D$, and $C O M B \_R M \_S T D$. We exclude the governance variable (GOVERNANCE) from the regression models in Table 4 to avoid double effects of governance in the regression Equation (1). In Table 8, Models 1, 3, and 5 provide the 
empirical results on the relationship between $D I F F$ and three RAEM measures: $C O M B \_R M, C O M B_{-} E X P \_P R O D$, and $C O M B_{-} R M \_S T D$. The strategy variable $(D I F F)$ is significant and negatively associated with $\bar{C} O M \bar{B}_{-} R M(-$ $0.211, \mathrm{p}<0.01), C O M B \_E X P \_P R O D(-0.188, \mathrm{p}<0.01)$, and $C O M B \_R M \_S T D(-1.867, \mathrm{p}<0.01)$, respectively. In Table 8, Models 2, 4, and 6 show that $U N A D J \_C S R^{*} D I F F$ is significant and negatively associated with COMB_RM ($0.716, \mathrm{p}<0.01), C O M B \_E X P \_P R O D(-0 . \overline{6} 38, \mathrm{p}<0.01)$, and COMB_RM_STD $(-6.189, \mathrm{p}<0.01)$, respectively. Thus, our results in Table 4 also remain unchanged when we use original $\overline{C S R}$ scores.

Table 8. Multiple Regressions of Other Measures of RAEM on DIFF and UNADJ_CSR*DIFF

\begin{tabular}{|c|c|c|c|c|c|c|c|}
\hline \multirow[b]{3}{*}{$\begin{array}{c}\text { Independent } \\
\text { variables }\end{array}$} & \multirow[b]{3}{*}{$\begin{array}{l}\text { Pred. } \\
\text { Sign }\end{array}$} & \multicolumn{6}{|c|}{ Dependent variable } \\
\hline & & Model 1 & Model 2 & Model 3 & Model 4 & Model 5 & Model 6 \\
\hline & & $\begin{array}{c}C O M B \_R M \\
\text { Coeff. } \\
\text { (t-stat) }\end{array}$ & $\begin{array}{c}C O M B \_R M \\
\text { Coeff. } \\
\text { (t-stat) }\end{array}$ & $\begin{array}{c}\text { COMB_EXP } \\
\text { PROD } \\
\text { Coeff. } \\
\text { (t-stat) }\end{array}$ & $\begin{array}{c}C O M B \_E X \\
P_{-} P R O D \\
\text { Coeff. } \\
\text { (t-stat) }\end{array}$ & $\begin{array}{c}C O M B \_R M \\
S T D \\
\bar{C} \text { Coeff. } \\
\text { (t-stat) }\end{array}$ & $\begin{array}{c}C O M B \_R M \\
\text { STD } \\
\text { Coeff. } \\
\text { (t-stat) }\end{array}$ \\
\hline \multirow{2}{*}{ UNADJ_CSR } & \multirow{2}{*}{ - } & $-0.605^{* * *}$ & -0.239 & $-0.640^{* * *}$ & $-0.313^{* *}$ & $-4.899^{* * *}$ & -1.729 \\
\hline & & $(-4.16)$ & $(-1.44)$ & $(-5.03)$ & $(-2.44)$ & $(-3.72)$ & $(-1.11)$ \\
\hline \multirow{2}{*}{ DIFF (H1) } & \multirow[b]{2}{*}{-} & $-0.211^{* * *}$ & $2.529^{* *}$ & $-0.188^{* * *}$ & $2.256^{* *}$ & $-1.867^{* * *}$ & $21.828^{* *}$ \\
\hline & & $(-9.30)$ & $(2.47)$ & $(-9.98)$ & $(2.49)$ & $(-8.89)$ & $(2.39)$ \\
\hline \multirow{2}{*}{$\begin{array}{l}\text { UNADJ_CSR *DIFF } \\
(H 2)\end{array}$} & \multirow{2}{*}{ - } & & $-0.716^{* * *}$ & & $-0.638^{* * *}$ & & $-6.189^{* * * *}$ \\
\hline & & & $(-2.67)$ & & $(-2.70)$ & & $(-2.59)$ \\
\hline \multirow{2}{*}{$A B S \_D A$} & \multirow{2}{*}{$?$} & 0.147 & 0.125 & 0.095 & 0.075 & 1.450 & 1.253 \\
\hline & & $(0.62)$ & $(0.53)$ & $(0.52)$ & $(0.42)$ & $(0.63)$ & $(0.55)$ \\
\hline \multirow{2}{*}{ SIZE } & \multirow{2}{*}{$?$} & $0.017^{* *}$ & $0.017^{* *}$ & $0.028^{* * *}$ & $0.027^{* * *}$ & 0.104 & 0.102 \\
\hline & & $(2.15)$ & $(2.16)$ & $(4.24)$ & $(4.29)$ & $(1.41)$ & $(1.41)$ \\
\hline \multirow{2}{*}{ GROWTH } & \multirow{2}{*}{$?$} & 0.018 & 0.027 & 0.022 & 0.030 & 0.109 & 0.181 \\
\hline & & $(0.18)$ & $(0.26)$ & $(0.24)$ & $(0.31)$ & $(0.12)$ & $(0.20)$ \\
\hline \multirow{2}{*}{$A D J \_R O A$} & \multirow[b]{2}{*}{ - } & $-1.089^{* * *}$ & $-1.030^{* * *}$ & $-0.675^{* * *}$ & $-0.623^{* * *}$ & $-10.532^{* * *}$ & $-10.023^{* * *}$ \\
\hline & & $(-6.04)$ & $(-5.73)$ & $(-4.62)$ & $(-4.36)$ & $(-6.28)$ & $(-5.98)$ \\
\hline \multirow{2}{*}{$B I G 4$} & \multirow{2}{*}{ - } & -0.003 & -0.000 & -0.005 & -0.002 & -0.026 & 0.001 \\
\hline & & $(-0.20)$ & $(-0.02)$ & $(-0.33)$ & $(-0.13)$ & $(-0.17)$ & $(0.00)$ \\
\hline \multirow{2}{*}{ LEVERAGE } & \multirow{2}{*}{+} & -0.007 & -0.013 & -0.086 & $-0.091 *$ & 0.240 & 0.192 \\
\hline & & $(-0.12)$ & $(-0.21)$ & $(-1.56)$ & $(-1.67)$ & $(0.41)$ & $(0.33)$ \\
\hline \multirow{2}{*}{ EQUITY } & \multirow{2}{*}{+} & -0.019 & -0.022 & -0.023 & -0.025 & -0.155 & -0.176 \\
\hline & & $(-0.94)$ & $(-1.06)$ & $(-1.34)$ & $(-1.48)$ & $(-0.82)$ & $(-0.93)$ \\
\hline \multirow{2}{*}{ FIRM_AGE } & \multirow{2}{*}{$?$} & $0.061^{* *}$ & $0.058^{* *}$ & $0.061^{* * *}$ & $0.059^{* *}$ & $0.488^{* *}$ & $0.461^{* *}$ \\
\hline & & $(2.44)$ & $(2.40)$ & $(2.59)$ & $(2.57)$ & $(2.27)$ & $(2.21)$ \\
\hline \multirow{2}{*}{ CONSTANT } & & $1.750^{* * *}$ & 0.378 & $1.638^{* * *}$ & 0.415 & $15.323^{* * *}$ & 3.462 \\
\hline & & $(3.60)$ & $(0.63)$ & $(3.93)$ & $(0.90)$ & $(3.47)$ & $(0.62)$ \\
\hline Industry dummies & & Included & Included & Included & Included & Included & Included \\
\hline Year dummies & & Included & Included & Included & Included & Included & Included \\
\hline Mean of VIF & & 1.96 & n.a. & 1.96 & n.a. & 1.96 & n.a. \\
\hline Adjusted $\mathrm{R}^{2}$ & & 0.35 & 0.36 & 0.35 & 0.36 & 0.35 & 0.36 \\
\hline $\mathrm{F}$ & & $18.70^{* * *}$ & $18.34^{* * *}$ & $17.21^{* * *}$ & $16.61^{* * *}$ & $17.45^{* * *}$ & $16.94^{* * *}$ \\
\hline $\mathrm{n}$ & & 659 & 659 & 659 & 659 & 659 & 659 \\
\hline
\end{tabular}

Variable Definitions:

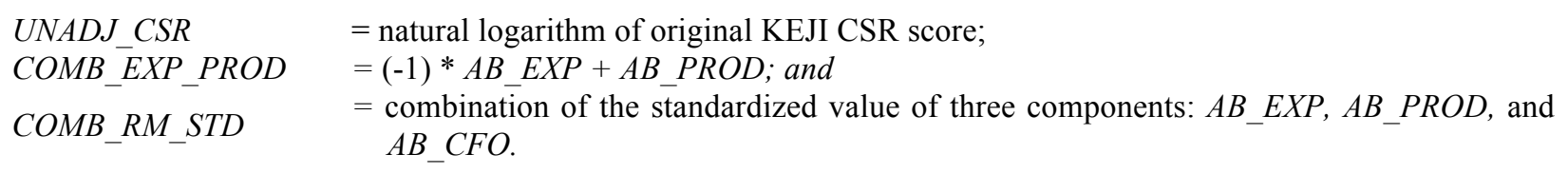




\section{SUMMARY AND CONCLUSION}

We explore whether firms pursuing differentiation strategy behave differently in constraining RAEM as compared to firms pursuing cost leadership strategy. We hypothesize that firms pursuing the differentiation strategy that emphasizes the reputation of brand image and corporate image are likely to refrain RAEM to implement their differentiation strategy. Further, considering CSR is closely associated with the differentiation strategy, we examine whether synergy effect of CSR and differentiation strategy strengthens the relationship between differentiation strategy and RAEM.

Our findings support the hypotheses that differentiation strategy is negatively associated with RAEM and CSR strengthens the negative relationship between differentiation strategy and RAEM. Our results suggest that differentiation strategy and CSR activities jointly play a significant role in constraining RAEM. Our results remain robust after we control for alternative measures of RAEM, differentiation strategy, and CSR scores.

Collectively, the results are consistent with the notion that differentiation strategy and CSR activities emphasize the relationship with diverse stakeholders such as customers, community, and employees to enhance a good firm and brand image. Firms pursuing the differentiation strategy are likely to constrain RAEM because RAEM works against implementing the differentiation strategy. Thus, differentiation strategy and CSR activities jointly constrain RAEM that employs sales discount, overproduction, cutting SGA expenses, thereby damaging the relationship with stakeholders. The evidence of this study provides insight for researchers and outside investors. Researchers need to consider the firm's differentiation strategy emphasizing a high level of R\&D and advertising in future studies on RAEM as a control variable. Further, considering CSR is congruent with the differentiation strategy, a firm's production strategy needs to be considered in future studies on CSR. The results of this study help investors in understanding the characteristics of firms that deliver more transparent financial information. When they need to examine accounting data to make an important investment decision, they can consider the specific firm's characteristics such as the product strategy and CSR activities.

\section{AUTHOR BIOGRAPHIES}

Sungbin Chun, Ph.D. and Professor of Accounting, has been teaching at Business School at Sogang University, AACSB accredited school for more than 30 years. She received her Ph.D. degree in Accounting from the University of California Berkeley. Sungbin Chun, School of Business, Sogang University, 35 Baekbumro Mapogu, Seoul, Korea, 121-742. E-mail: younghwa@sogang.ac.kr (Main author).

Eunho Cho, Ph.D. and Assistant Professor of Accounting, has been teaching at School of Management of New York Institute of Technology, Nanjing Campus (AACSB accredited school) since September 1, 2015. He taught at Sogang University from 2012 and Korea Banking Institution from 2004, respectively. He obtained Accounting doctor degree at Sogang University on February, 2015 and Master degree of Financial Engineering from KAIST. He also worked for finance and manufacturing company for 9 years and 4 years, respectively. His research focuses on the CSR, earnings management, corporate governance, international business, and valuation. He achieved the certificate of CFA, AICPA and FRM which are conferred by US based institutions. Eunho Cho, New York Institute of Technology, Nanjing Campus, P.O.B. 694 \#9 Wenyuan Lu, Qixia District Nanjing University of Post and Telecommunications College of Overseas Education, Nanjing Jiangsu 210023, PRC. E-mail: ehcho@ nyit.edu (Corresponding author).

\section{REFERENCES}

Accenture. (2014). Accenture sustainability performance management delivering business value from sustainability strategy. New York: Accenture.

Anthony, J. H., \& Ramesh, K. (1992). Association between accounting performance measures and stock prices: A test of the life cycle hypothesis. Journal of Accounting and Economics, 15(2), 203-227.

Ashbaugh-Skaife, H., Collins, D. W., \& Kinney Jr, W. R. (2007). The discovery and reporting of internal control deficiencies prior to SOX-mandated audits. Journal of Accounting and Economics, 44(1), 166-192.

Baber, W. R., Fairfield, P. M., \& Haggard, J. A. (1991). The effect of concern about reported income on discretionary spending decisions: The case of research and development. Accounting Review, 818-829.

Copyright by author(s); $\underline{\text { CC-BY }}$ 
Ball, R., \& Foster, G. (1982). Corporate financial reporting: A methodological review of empirical research. Journal of Accounting Research, 161-234.

Balsam, S., Haw, I.-M., \& Lilien, S. B. (1995). Mandated accounting changes and managerial discretion. Journal of Accounting and Economics, 20(1), 3-29.

Becker, C. L., DeFond, M. L., Jiambalvo, J., \& Subramanyam, K. (1998). The effect of audit quality on earnings management. Contemporary Accounting Research, 15(1), 1-24.

Beneish, M. D. (1997). Detecting GAAP violation: Implications for assessing earnings management among firms with extreme financial performance. Journal of Accounting and Public Policy, 16(3), 271-309.

Bens, D. A., Nagar, V., \& Wong, M. (2002). Real investment implications of employee stock option exercises. Journal of Accounting Research, 40(2), 359-393.

Beurden, P. \& Gössling, T. (2008). The worth of values - A literature review on the relation between corporate social and

financial performance. Journal of Business Ethics, 82(2), 407-424.

Boehe, D. M., \& Cruz, L. B. (2010). Corporate social responsibility, product differentiation strategy and export performance. Journal of Business Ethics, 91(2), 325-346.

Bushee, B. J. (1998). The influence of institutional investors on myopic R\&D investment behavior. Accounting Review, $305-333$.

Cheng, P., Man, P., \& Yi, C. H. (2013). The impact of product market competition on earnings quality. Accounting \& Finance, 53(1), 137-162.

Cheng, S. (2004). R\&D expenditures and CEO compensation. The Accounting Review, 79(2), 305-328.

Cho, E. H., \& Chun, S. B. (2016). Corporate social responsibility, real activities earnings management, and corporate governance: Evidence from Korea. Asia-Pacific Journal of Accounting \& Economics, 23(4), 400-431.

Choi, B., Lee, D., \& Park, Y. (2013). Corporate social responsibility, corporate governance and earnings quality: Evidence from Korea. Corporate Governance: An International Review, 21(5), 447-467.

Choi, H., \& Moon, D. (2013). The relationship between corporate social responsibilities and accounting transparency. Korean Accounting Review, 38(1), 135-171.

Choi, J., Kwak, Y., \& Choe, C. (2010). Corporate social responsibility and corporate financial performance: Evidence from Korea. Australian Journal of Management, 35(3), 291-311.

Choi, T. H., \& Pae, J. (2011). Business ethics and financial reporting quality: Evidence from Korea. Journal of Business Ethics, $103(3), 403-427$.

Chun, H., \& Cha, S. (2012). Real earnings management and cost of equity capital. Journal of Taxation and Accounting, 13(1), 99-130.

Chun, S. B., Kwon, H. J., Kim, M. I., Kim, S. H., \& Lee, A. Y. (2012). Financial reporting patterns of Korean firms: Based on the survey of chief financial officers. Korean Accounting Journal, 21(6), 97-132.

Cohen, D. A., Dey, A., \& Lys, T. Z. (2008). Real and accrual-based earnings management in the pre-and post-Sarbanes-Oxley periods. The Accounting Review, 83(3), 757-787.

Cohen, D., Mashruwala, R., \& Zach, T. (2009). The use of advertising activities to meet earnings benchmarks: evidence from monthly data. Review of Accounting Studies, 15(4), 808-832.

DeAngelo, L. E. (1981). Auditor size and audit quality. Journal of Accounting and Economics, 3(3), 183-199.

Dechow, P. M., \& Sloan, R. G. (1991). Executive incentives and the horizon problem: An empirical investigation. Journal of Accounting and Economics, 14(1), 51-89.

Dechow, P., Ge, W., \& Schrand, C. (2010). Understanding earnings quality: A review of the proxies, their determinants and their consequences. Journal of Accounting and Economics, 50(2-3), 344-401.

DeFond, M. L., \& Park, C. W. (1997). Smoothing income in anticipation of future earnings. Journal of Accounting and Economics, 23(2), 115-139.

DeFond, M. L., \& Subramanyam, K. (1998). Auditor changes and discretionary accruals. Journal of Accounting and Economics, 25(1), 35-67.

Dhaliwal, D. S., Radhakrishnan, S., Tsang, A., \& Yang, Y. G. (2012). Nonfinancial disclosure and analyst forecast accuracy: International evidence on corporate social responsibility disclosure. The Accounting Review, 87(3), 723-759.

Doyle, J. T., Ge, W., \& McVay, S. (2007). Accruals quality and internal control over financial reporting. The Accounting Review, $82(5), 1141-1170$.

Dye, R. A. (1993). Auditing standards, legal liability, and auditor wealth. Journal of Political Economy, 101(5), 887-914.

Francis, J. R., Maydew, E. L., \& Sparks, H. C. (1999). The role of Big 6 auditors in the credible reporting of accruals. Auditing: A Journal of Practice \& Theory, 18(2), 17-34.

Gao, Y. (2011). CSR in an emerging country: A content analysis of CSR reports of listed companies. Baltic Journal of Management, 6(2), 263-291.

Graham, J. R., Harvey, C. R., \& Rajgopal, S. (2005). The economic implications of corporate financial reporting. Journal of Accounting and Economics, 40(1), 3-73.

Gunny, K. A. (2005). What are the consequences of real earnings management? (Working paper), University of California, Berkeley.

Hambrick, D. C. (1983). High profit strategies in mature capital goods industries: A contingency approach. Academy of 
Management Journal, 26(4), 687-707.

Harjoto, M. A., \& Jo, H. (2011). Corporate Governance and CSR Nexus. Journal of Business Ethics, 100(1), $45-67$.

Hull, C. E., \& Rothenberg, S. (2008). Firm performance: The interactions of corporate social performance with innovation and industry differentiation. Strategic Management Journal, 29(7), 781-789.

Jackson, S. B., \& Wilcox, W. E. (2000). Do managers grant sales price reductions to avoid losses and declines in earnings and sales? Quarterly Journal of Business and Economics, 3-20.

KEJI. (2011). The 20th corporate award of economic justice: Korea Economic Justice Institute.

Kim, A., \& Yoo, J. (2013). The moderating effect of corporate governance on the relations between corporate social responsibility and firm value. Korean Journal of Business Administration, 26(2), 219-240.

Kim, J.-B., \& Sohn, B. C. (2013). Real earnings management and cost of capital. Journal of Accounting and Public Policy, 32(6), 518-543.

Kim, J., Bae, J., \& Goh, J. (2009). The effect of real earnings management on long term performance. Korean Accounting Review, 34(4), 31-70.

Kim, J., Goh, J., \& Koh, Y. (2008). Real earnings management to avoid loss and smooth income. Korean Accounting Journal, 17(4), 31-63.

Kim, S., \& Kim, Y. (2015). Product market competition on the effectiveness of internal control. Asia-Pacific Journal of Accounting \& Economics, 1-20.

Kim, Y., \& Park, M. S. (2005). Pricing of seasoned equity offers and earnings management. Journal of Financial and Quantitative Analysis, 40(02), 435-463.

Kim, Y., Park, M. S., \& Wier, B. (2012). Is earnings quality associated with corporate social responsibility? The Accounting Review, 87(3), 761-796.

Kook, C., \& Kang, Y. (2011). Corporate social responsibility, corporate governance, and firm value. Korean Journal of Financial Studies, 40(5), 713-748.

Kothari, S. P., Leone, A. J., \& Wasley, C. E. (2005). Performance matched discretionary accrual measures. Journal of Accounting and Economics, 39(1), 163-197.

Lee, C.-W. J., Li, L. Y., \& Yue, H. (2006). Performance, growth and earnings management. Review of Accounting Studies, 11(23), 305-334.

Leuz, C., Nanda, D., \& Wysocki, P. D. (2003). Earnings management and investor protection: an international comparison. Journal of Financial Economics, 69(3), 505-527.

Lev, B. (1983). Some economic determinants of time-series properties of earnings. Journal of Accounting and Economics, 5, 3148.

Li, X. (2010). The impacts of product market competition on the quantity and quality of voluntary disclosures. Review of Accounting Studies, 15(3), 663-711.

Lien, Y.-C., \& Li, S. (2013). Does diversification add firm value in emerging economies? Effect of corporate governance. Journal of Business Research, 66(12), 2425-2430.

Lim, H., \& Choi, J. (2013). Corporate social responsibility and earnings management: Does the external business ethics portray internal ethics? Korean Accounting Journal, 22(5), 257-309.

McWilliams, A., \& Siegel, D. (2000). Corporate social responsibility and financial performance: Correlation or misspecification? Strategic Management Journal, 21(5), 603-609.

McWilliams, A., \& Siegel, D. (2001). Corporate social responsibility: A theory of the firm perspective. Academy of Management Review, 26(1), 117-127.

McWilliams, A., Siegel, D., \& Wright, P. M. (2006). Corporate social responsibility: Strategic implications. Journal of Management Studies, 43(1), 1-18.

Miller, D. (1986). Configurations of strategy and structure: Towards a synthesis. Strategic Management Journal, 7(3), $233-249$.

Myers, J. N., Myers, L. A., \& Omer, T. C. (2003). Exploring the term of the auditor-client relationship and the quality of earnings: A case for mandatory auditor rotation? The Accounting Review, 78(3), 779-799.

Oh, W., Chang, Y., \& Martynov, A. (2011). The effect of ownership structure on corporate social responsibility: Empirical evidence from Korea. Journal of Business Ethics, 104(2), 283-297.

Osma, B. G. (2008). Board independence and real earnings management: the case of R\&D expenditure. Corporate Governance: An International Review, 16(2), 116-131.

Park, K. W., Park, R. S., \& Hwang, L. S. (2005). Corporate governance and the distribution of shareholder wealth. Asia Pacific Journal of Financial Studies, 34, 149-188.

Porter, M. E. (1980). Competitive strategies. New York: The Free Press.

Porter, M. E., \& Kramer, M. R. (2006). Strategy and society: The link between corporate social responsibility and competitive advantage. Harvard Business Review, 84(12), 78-92.

Prior, D., Surroca, J., \& Tribó, J. A. (2008). Are socially responsible managers really ethical? Exploring the relationship between earnings management and corporate social responsibility. Corporate Governance: An International Review, 16(3), 160177.

Reinhardt, F. L., Stavins, R. N., \& Vietor, R. H. K. (2008). Corporate Social Responsibility Through an Economic Lens. Review 
of Environmental Economics and Policy, 2(2), 219-239.

Richardson, S. A., Sloan, R. G., Soliman, M. T., \& Tuna, I. (2005). Accrual reliability, earnings persistence and stock prices. Journal of Accounting and Economics, 39(3), 437-485.

Roychowdhury, S. (2006). Earnings management through real activities manipulation. Journal of Accounting and Economics, 42(3), 335-370.

Schipper, K. (1989). Commentary on earnings management. Accounting Horizons, 91-102.

Shin, J. Y., Suh, C. W., \& Park, J. I. (2012). The effect of corporate governance on the association between earnings and credit ratings. Korean Management Review, 41, 1309-1345.

Siegel, D. S., \& Vitaliano, D. F. (2007). An empirical analysis of the strategic use of corporate social responsibility. Journal of Economics \& Management Strategy, 16(3), 773-792.

Strike, V. M., Gao, J., \& Bansal, P. (2006). Being good while being bad: Social responsibility and the international diversification of US firms. Journal of International Business Studies, 37(6), 850-862.

Teoh, S. H., Welch, I., \& Wong, T. J. (1998). Earnings management and the long-run market performance of initial public offerings. The Journal of Finance, 53(6), 1935-1974.

Thomas, J. K., \& Zhang, H. (2002). Inventory changes and future returns. Review of Accounting Studies, 7(2-3), $163-187$.

Waddock, S. A., \& Graves, S. B. (1997). The corporate social performance-Financial performance link. Strategic Management Journal, 8(4), 303-319.

Watts, R. L., \& Zimmerman, J. L. (1986). Positive accounting theory.

Zang, A. Y. (2012). Evidence on the trade-off between real activities manipulation and accrual-based earnings management. The Accounting Review, 87(2), 675-703. 


\section{APPENDIX A}

\begin{tabular}{|c|c|}
\hline Variable & Definition \\
\hline$A B \_C F O$ & abnormal cash flows from operations; \\
\hline$A B \_E X P$ & 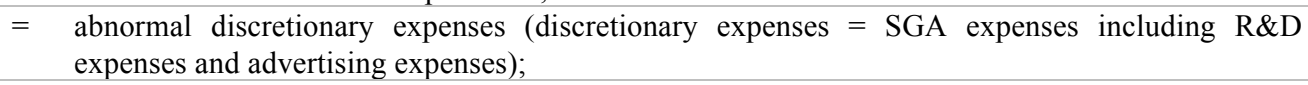 \\
\hline$A B \_P R O D$ & $=\quad$ abnormal production costs (production costs $=$ cost of goods sold + change in inventories) \\
\hline$A B S \_D A$ & $\begin{array}{l}=\text { absolute value of discretionary accruals measured using the modified Jones model including } \\
\text { lagged ROA; }\end{array}$ \\
\hline$A D J \_C S R$ & $\begin{array}{l}=\text { natural logarithm of adjusted CSR score (Original KEJI CSR score - soundness score - fairness } \\
\text { score); }\end{array}$ \\
\hline$A D J \_C S R * D I F F$ & $=\quad$ interaction term, measured by $A D J \_C S R$ times $D I F F$; \\
\hline$A D J \_R O A$ & $\begin{array}{l}=\quad \text { industry mean-adjusted return on assets }(\mathrm{ROA}) \text { in the prior year }(\mathrm{ROA}=\text { income from continuing } \\
\text { operation divided by lagged total assets); }\end{array}$ \\
\hline$B I G 4$ & $=\quad$ indicator variable that is 1 if big 4 accounting firms audit the company, and 0 otherwise; \\
\hline COMB_EXP_PROD & $=(-1) * A B \_E X P+A B \_P R O D$ \\
\hline$C O M B \_E X P \_P R O D$ & $=(-1) * A B \_E X P+A B \_P R O D$ \\
\hline$C O M B \_R M$ & $=\quad-\mathrm{AB} \_\mathrm{CFO}+\mathrm{AB} \_\mathrm{PROD}-\mathrm{AB} \_\mathrm{EXP}$ \\
\hline$C O M B \_R M \_S T D$ & $=\quad$ combination of the standardized value of three components: $A B \_E X P, A B \_P R O D$, and $A B \_C F O ;$ \\
\hline$C O M B \_R M \_S T D$ & combination of the standardized value of three components: $A B \_E X P, A B \_P R O D$, and $A B \_C F O$; \\
\hline$D I F F$ & $\begin{array}{l}=\text { indicator variable that equals } 1 \text { if firms pursue the differentiation strategy measured by } R \& D \text { and } \\
\text { advertisement intensity measured by the mean of R\&D expenditures and advertisement divided } \\
\text { by sales for } 6 \text { years, respectively, and } 0 \text { otherwise; }\end{array}$ \\
\hline EQUITY & $=\quad$ indicator variable that is 1 if the firm has equity issuing in the following year, and 0 otherwise; \\
\hline FIRM AGE & $=$ natural logarithm of the number of years since the firm's establishment plus one; \\
\hline GOVERNANCE & $=$ natural logarithm of total governance score measured as KCGS Index; \\
\hline GROWTH & $=$ average sales growth rate for the prior three years; \\
\hline LEVERAGE & $=$ total liability divided by total assets at the end of fiscal year; \\
\hline$N E G A \_A B \_C F O$ & $=(-1) * A B \_C F O$ \\
\hline$N E G A \_A B \_E X P$ & $=(-1) * A B \_E X P$ \\
\hline SIZE & $=$ natural logarithm of total asset at the end of fiscal year; and \\
\hline UNADJCSR & $=$ natural logarithm of original KEJI CSR score. \\
\hline
\end{tabular}

\section{ENDNOTES}

\footnotetext{
${ }^{\mathrm{i}} A B_{-} C F O$ is abnormal cash flows from operations. $A B_{-} P R O D$ is abnormal production costs (production costs $=$ cost of goods sold + change in inventories). $A B_{-} E X P$ is abnormal discretionary expenses (discretionary expenses $=$ SGA expenses including R\&D expenses and advertising expenses).

${ }^{\text {ii } W e ~ e m p l o y ~ c o m p r e h e n s i v e ~ c o r p o r a t e ~ g o v e r n a n c e ~ s c o r e ~ K o r e a ~ C o r p o r a t e ~ G o v e r n a n c e ~ S e r v i c e ~ p r o v i d e s . ~ T h i s ~ s c o r e ~ i s ~ w i d e l y ~ a c c e p t e d ~ a n d ~ u s e d ~}$ in prior studies (Park, Park \& Hwang, 2005; Shin, Suh \& Park, 2012; Cho \& Chun, 2016). This score consists of five categories: shareholders' right protection, board of directors, disclosure, audit institute, and operation income distribution.

${ }^{\text {iii }}$ The estimation equation for discretionary accrual is as follows: $T A_{t} / A_{t-1}=\alpha_{0}+\alpha_{1}\left(1 / A_{t-l}\right)+\alpha_{2}\left(\left(\Delta S_{t}-\Delta A R_{t}\right) / A_{t-l}\right)+\alpha_{3}\left(P P E_{t} / A_{t-l}\right)+\alpha_{4}\left(I B X I_{t-1} / A_{t-l}\right)+\varepsilon_{t} T_{h e}$ variable definitions are as follows: $T A_{t}=$ total accruals for a firm at the end of year t; $A_{t-1}=$ total assets at the end of year t-1; $\Delta S_{t}=$ change in net sales at the end of year $\mathrm{t}$ from year $\mathrm{t}-1 ; \triangle A R_{t}=$ change in net receivables at the end of year $\mathrm{t} ; P P E_{t}=$ gross property, plant, and equipment at the end of year $\mathrm{t} ; I B X I_{t-1}=$ income before extraordinary items at the end of year $\mathrm{t}-1$.

${ }^{\text {iv }}$ Because the results of control variables in Models 1, 2, and 3 are similar to that of model 4, we only explain the coefficients of control variables in Model 4.
} 